\title{
Risk Assessment of Joint Sealing Tape in Joints between Precast Concrete Sandwich Panels Resilient to Climate Change
}

\author{
Charlotte Svensson Tengberg ${ }^{1, *(D)}$, Lars Olsson ${ }^{2}$ and Carl-Eric Hagentoft ${ }^{1}$ \\ 1 Department of Architecture and Civil Engineering, Chalmers University of Technology, \\ SE-412 96 Gothenburg, Sweden; carl-eric.hagentoft@chalmers.se \\ 2 RISE Research Institutes of Sweden, SE-501 15 Borås, Sweden; lars.olsson@ri.se \\ * Correspondence: charlotte.tengberg@chalmers.se
}

Citation: Svensson Tengberg, C.; Olsson, L.; Hagentoft, C.-E. Risk Assessment of Joint Sealing Tape in Joints between Precast Concrete Sandwich Panels Resilient to Climate Change. Buildings 2021, 11, 343. https://doi.org/10.3390/ buildings 11080343

Academic Editor: Michael A. Lacasse

Received: 28 June 2021

Accepted: 4 August 2021

Published: 11 August 2021

Publisher's Note: MDPI stays neutral with regard to jurisdictional claims in published maps and institutional affiliations.

Copyright: (c) 2021 by the authors. Licensee MDPI, Basel, Switzerland. This article is an open access article distributed under the terms and conditions of the Creative Commons Attribution (CC BY) license (https:// creativecommons.org/licenses/by/ $4.0 /)$.

\begin{abstract}
Lately, a new technical solution, pre-compressed joint sealing tapes in precast concrete sandwich panel facades, has been introduced in Sweden. Although the consequences of performance failure can go far beyond the component, affecting the building, the introduction has gained little attention in terms of risk assessment in the literature and in industry. Instead, reference cases are used as verification without formal evaluation, potentially leading to serial failure. The aim of this paper was to provide guidance on how a design-build contractor should handle this new technical solution. A risk assessment framework using a design-build contractor's perspective was applied to the case. The framework addresses new technical solutions or adaption to new conditions (e.g., climate change) with the aim of preventing serial failures. Moisture conditions within the joints were simulated using present and future climates, and probabilities of failure were assessed using the Monte Carlo method. The results of the study included identified risks of failure associated with the solution and factors influencing the probability of failure. A main issue was the exposure of the facade to driving rain but also run-off areas and imperfections in the application of the joint sealing tape. Future climate changes affect performance negatively. In conclusion, the new technical solution might be possible to use if draining potential is ensured in all detailed designs and a set of recommendations, including full-scale testing, is provided for the design-build contractor.
\end{abstract}

Keywords: joint sealing tape; precast concrete; driving rain; moisture safety; risk assessment; new technical solutions; climate change

\section{Introduction}

In Sweden, the traditional solution for joints between precast concrete sandwich panel facades is using soft mastic applied on a backing rod, having small tubes for depressurisation, drainage, and ventilation of air space behind joints. However, the use of pre-compressed joint sealing tape in joints is gaining ground; sporadic examples of this solution can be found as early as 2011, but during the last few years, there has been an apparent increase in favour of this solution. The introduction has been driven by suppliers of joint sealing tapes, offering design-build contractors a new technical solution with anticipated cost-effectiveness with less weather-dependent application and a potential solution to earlier experienced moisture problems in precast concrete sandwich facades [1].

The introduction of joint sealing tape has gained little attention in terms of risk assessment, both in the literature and in industry, as it is a non-load bearing component of a larger system. From the perspective of the precast structure, the change might be perceived as incremental although the consequences can go far beyond the component and affect the building as well as the facade. The picture is also complicated by several actors being involved (e.g., supplier of precast panels, supplier of joint sealing tape and designbuild contractor), sharing the responsibility of fulfilling the performance requirements of the facade. Furthermore, as buildings have an expected life span of 50 to 100 years, there is potentially the impact of climate change on its performance. Data available to 
the design-build contractor are mainly a few essential characteristics of the product as defined in the applicable European Assessment Document [2], which possibly does not contain sufficient information for a risk assessment of the full technical solution applied in a building from a design-build contractor's perspective. Few studies on performance were found, only [3] and [4] specifically addressed the watertightness of joint sealing tapes in precast concrete sandwich panels. Instead, reference cases are referred to by suppliers to verify performance, but these often lack adequate assessment and documentation leaving the design-build contractor with an incomplete basis for decision making. This is not unique to this technical solution. When interviewing actors in the construction sector [5], shortcomings were identified related to the design-build contractors' assessment of new technical solutions: varied resources available for evaluation, lack of a common evaluation methodology and, possibly, a disproportional trust in suppliers' information. To address these issues a new systematic approach for adequate risk assessment for new technical solutions using a design-build contractor's perspective was suggested in [6]. On the basis of estimated market potential or anticipated benefits, the new technical solution using joint sealing tape in precast concrete sandwich panel facades was identified to be of interest by a design-build contractor. By applying the suggested framework to joint sealing tapes in precast concrete sandwich facades, an adequate yet cost effective evaluation to guide the design-build contractor is expected.

\section{Aim and Objective}

The aim of this paper was to provide guidance on how a design-build contractor should handle this new technical solution: joint sealing tape in joints between precast concrete sandwich panels. The objectives were to perform a risk assessment of joint sealing tape in joints between precast concrete sandwich panels from a design-build contractor's perspective using an elaborated risk assessment framework, and based on the assessment, to provide recommendations on implementation of the solution. In addition, the resilience of the structure was quantified in simulations using experimental data on water leakage. Reflections on practical insights of the used framework are also presented.

This paper is a part of a research project initiated with the overall aim of contributing to reducing serial failures when introducing new technical solutions in the construction industry.

\section{Method}

This work applies the framework suggested in [6] (based on IEA Annex $55[7,8]$ ) on joint sealing tape in precast concrete sandwich panel facades-a new technical solution identified to have market potential and possible benefits by a design-build contractor. According to the framework, the assessment should be run at a general level as a standalone project where the design-build contractor takes part in the assessment. Before the assessment is started, the decision to initiate the risk assessment (Tollgate 0) should be made, and a project manager, a budget and an organisation should be assigned and directives and rationale for the assessment documented. The framework is divided into four steps, each using relevant established tools, and in between each step there is a tollgate (Figure 1). The stepwise process with tollgates was chosen as it was expected to have a good potential of reflecting the design-build contractor's interests and, at the same time, providing a cost-effective process.

- Scope. The scope is a specification of the new technical solution to be assessed, and it is important to establish a mutual understanding of what is being assessed. Important stakeholders should also be identified at this stage. The scope should comprise a thorough description divided into four parts: system boundaries, targets, strategies and limitations. Tools used are a stakeholder analysis, using a power versus interest grid combined with a participation planning matrix (e.g., [9]) and Annex I in Construction Products Regulation [10]. 


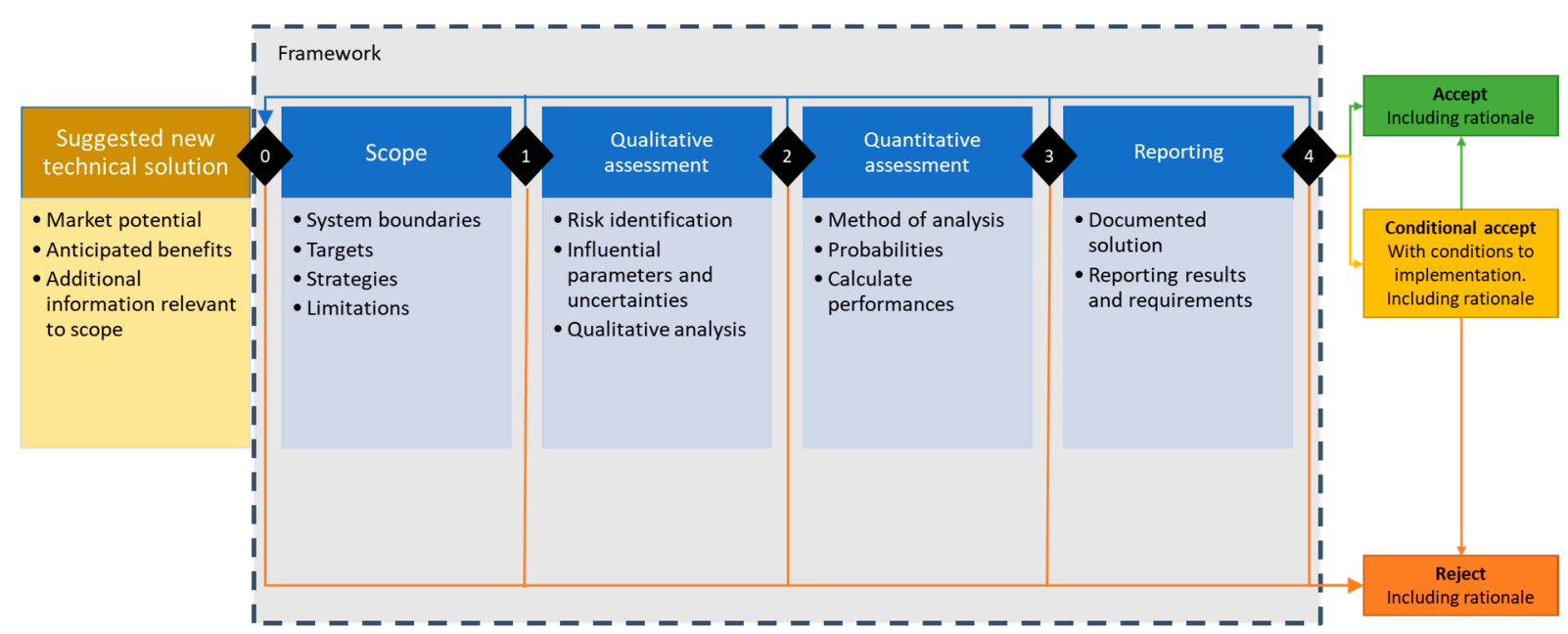

Figure 1. Workflow, as suggested in [6], and adapted from IEA Annex 55 [7,8]. Steps in the framework can be iterated as the work proceeds. Suggested tollgate decisions are 0: to initiate assessment, 1: to accept scope, 2, 3: to proceed with assessment and 4: to proceed to implementation. Decision can be to proceed, to revise, or not to proceed. Reprinted from [6].

In Tollgate 1 the scope describing the technical solution is assessed and a decision can be to proceed, to revise an earlier step (blue arrow) or to cancel the assessment (red arrow). For all decisions, the rationale is added to the documentation.

- Qualitative assessment. The qualitative assessment includes a risk identification, and identifying influential factors and their corresponding uncertainties, resulting in a qualitative assessment. Tools used for risk identification and structuring are expert workshops together with a literature review and a fault tree structure [11], respectively.

In Tollgate 2, the qualitative assessment could lead to the decision to proceed to a quantitative assessment or directly to reporting. If the qualitative assessment is incomplete or does not meet expectations, the qualitative assessment or scope should be revised (blue arrow). If the solution is considered non-viable, the solution is rejected (orange arrow). For all decisions, the rationale for the decision is added to the documentation.

- Quantitative assessment. A quantitative assessment is made on basis of the qualitative assessment of the scope. Important steps of the suitable method are identified for analysis, distinguishing probabilities and calculating the performance of the solution. Tools used are laboratory testing according to [12] for assessing performance of identified critical issues and, based on moisture mass balance of joint, Monte Carlo simulations for creating probability functions of performance based on long sequences ( $\geq 30$ years) of hourly values of climatic data.

In Tollgate 3 , the quantitative assessment could lead to the decision to proceed to reporting. If the quantitative assessment is either incomplete or not meeting the expectation, the quantitative assessment or earlier steps are revised (blue arrow). If the solution is considered not viable, the solution is rejected (orange arrow). For all decisions, the rationale for the decision is added to the documentation.

- Evaluation reporting. The input and results of the assessments are compiled, recommendations and a relevant specification of requirements are established, again from a design-build contractors' perspective, to serve as a basis of decisions. Verification and risk mitigation are suggested. Tools used are a table of assessment and recommendations. Recommendations can include references to a full-scale evaluation scheme.

In Tollgate 4, the case could be accepted as defined in the scope (green arrow) or conditionally accepted before implementation (yellow arrow). The conditions could concern a required evaluation during construction and operation. If the solution is considered non-viable, the solution is rejected (red arrow). For all decisions, the rationale for the decision is added to the documentation. 


\section{Scope of the Assessment}

System. The pre-compressed joint sealing tape is suggested to be applied in vertical and horizontal joints between precast concrete sandwich panels (Figure 2) and should contribute to the fulfilment of the performance requirements of a precast concrete sandwich panel facade, with the main issue contributing to a tight facade with a focus on rain tightness while handling the dimensional changes of the panels during an acceptable life span. Installation should also be possible at the building site. Maintenance during operation should also be considered. Stakeholders were identified and categorised into five groups: involve (listed in Table 1), communicate, inform, negotiate or watch. An expert group was formed with stakeholders representing the category involve.

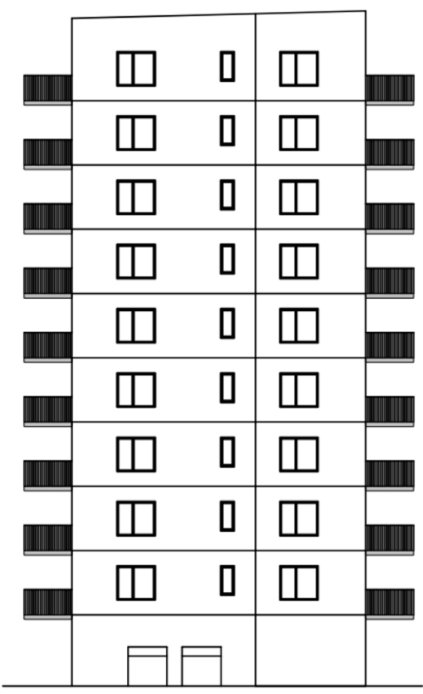

(a)

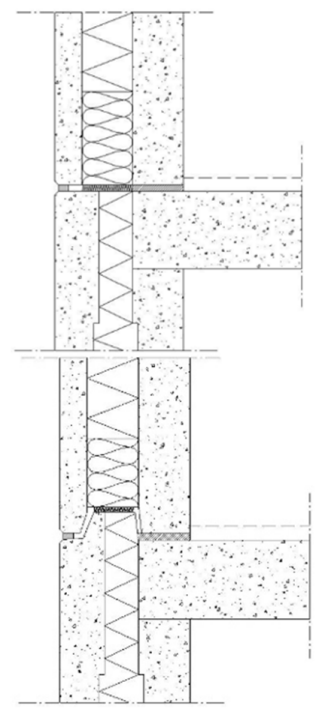

(b)

Figure 2. Suggested technical solution: (a) typical precast concrete facade; (b) example of the application in two different horizontal joints of precast concrete sandwich panels.

Table 1. Stakeholders identified as of interest to be involved (based on the analysis of stakeholders).

\begin{tabular}{ll}
\hline \multicolumn{1}{c}{ Actor } & \multicolumn{1}{c}{ Implementation/Handling } \\
\hline Contractors, trade/company level & $\begin{array}{l}\text { Contractor oversees the risk assessment. } \\
\text { Knowledge on construction. }\end{array}$ \\
\hline Developers/Property owners, trade/company level & $\begin{array}{l}\text { Trade/company level needs to accept change to new solution when evaluated. Provides } \\
\text { knowledge on property management. }\end{array}$ \\
\hline Contractors, project managers & $\begin{array}{l}\text { Contractor needs to accept the use of new solution when evaluated. Provides knowledge } \\
\text { on construction as well as connecting building parts and works. }\end{array}$ \\
\hline Suppliers, concrete panels & $\begin{array}{l}\text { Supplier needs to provide relevant documentation and guarantees. Provides knowledge } \\
\text { on concrete panels and experiences from other projects. }\end{array}$ \\
\hline Suppliers, pre-compressed sealing tape & $\begin{array}{l}\text { Supplier needs to provide relevant documentation and guarantees. Provides knowledge } \\
\text { on pre-compressed joint sealing tape. }\end{array}$ \\
\hline Sub-contractor, mounting concrete panels & \begin{tabular}{l} 
Provides knowledge on practical issues during mounting. \\
\hline Sub-contractor, sealant workers
\end{tabular} \\
\hline $\begin{array}{l}\text { Sub-contractor needs to provide guarantees when evaluated. Provides knowledge of } \\
\text { application of products. }\end{array}$ \\
\hline Design management/engineer & $\begin{array}{l}\text { Design management needs to accept change to new solution when evaluated. Provides } \\
\text { knowledge on relevant requirements in design. }\end{array}$ \\
\hline Moisture consultant & $\begin{array}{l}\text { Moisture consultant needs to make a risk assessment of solution and to accept change to } \\
\text { new solution when evaluated. Provides knowledge on moisture and moisture damage. }\end{array}$ \\
\hline Academia, building technology & \begin{tabular}{l} 
Academia will be represented as workshop leaders. \\
\hline Wild card
\end{tabular} \\
\hline
\end{tabular}


Targets. Overall targets of the building are defined as fulfilment of performance requirements. The performance requirements [13] apply to the whole building and should be broken down to requirements relevant to facades and, subsequently, to joints. Specifically, when assessing the joint, the target is to contribute to the fulfilment of performance requirements. Using basic requirements, as in the Construction Products Regulation, Annex I [10] as a starting point, applicable targets for the solution using joint sealing tape are listed in Table 2. When performance requirements applicable to the joint are unclear, known performance of traditional solution can be used as a benchmark.

Table 2. The Initial definition of targets and early assumptions to be further elaborated. Main topics for basic requirements defined as in the Construction Products Regulation, Annex I [10].

\begin{tabular}{|c|c|}
\hline $\begin{array}{l}\text { Main Topic: } \\
\text { Basic Requirement }\end{array}$ & Applicability to Technical Solution \\
\hline \multirow{4}{*}{ 1. Mechanical resistance and stability } & Load transfer in joints between panels assumed negligible. \\
\hline & Load transfer in joints between panel and structure assumed negligible. \\
\hline & Durability should be equivalent to traditional solution. * \\
\hline & The solution should be able to handle dimensional tolerances according to practice. \\
\hline 2. Safety in case of fire & Fire performance should be equivalent to traditional solution. * \\
\hline \multirow{4}{*}{ 3. Hygiene, health and environment } & The technical solutions should not hold any harmful substances. \\
\hline & $\begin{array}{l}\text { Critical moisture levels of materials in sandwich panels and materials of joints should not be } \\
\text { exceeded. Main materials are concrete panels, insulation material, reinforcement bars and sealing } \\
\text { material. The results should also be related to a current solution using sealant on backing rod } \\
\text { with a drained and ventilated air gap. }\end{array}$ \\
\hline & $\begin{array}{l}\text { Water should not be accumulated in construction. Water from driving rain through joints and } \\
\text { other normal imperfections should not be accumulated to harmful levels in sandwich panel, with } \\
\text { no leakage to indoors. The results should also be related to traditional solution. * }\end{array}$ \\
\hline & Air tightness should be equivalent to traditional solution. * \\
\hline 4. Safety in accessibility in use & Impact on safety in accessibility is assumed to be negligible. \\
\hline 5. Protection against noise & Acoustic performance should be equivalent to traditional solution. * \\
\hline 6. Energy economy and heat retention & $\begin{array}{l}\text { Thermal performance should be in line with traditional solution * or assessed to be of minor } \\
\text { impact to overall thermal performance. }\end{array}$ \\
\hline \multirow{2}{*}{ 7. Sustainable use of natural resources } & Other environmental issues not included in the assessment. \\
\hline & Disassembly is not included in the assessment. \\
\hline \multirow{3}{*}{ 8. Other } & $\begin{array}{l}\text { Working conditions should not cause any unacceptable work safety issues. Other work safety } \\
\text { issues not included. }\end{array}$ \\
\hline & Aesthetics should be acceptable over time. \\
\hline & Costs should be acceptable. \\
\hline
\end{tabular}

* Traditional solution: soft mastic on backing rod with small tubes for depressurisation, drainage and ventilation.

Expected consequences if targets on moisture performance are not fulfilled are leakage, leading primarily to excess water in wall and possibly in leakage leading to aesthetical problems and possibly to indoor problems [1]. Remedial measures usually involve deconstruction and change in materials, with a negative effect on residents and substantial costs.

Strategies. The studied precast concrete sandwich panels consist of an inner concrete panel, insulation (usually mineral wool, EPS, or other cellular plastic) and an outer concrete panel. Panels on top of each other are usually of the same length, resulting in a squared pattern of the facade. Sometimes this pattern is challenged creating tee joints or inverted tee joints. Examples of the wall system with joints between precast concrete sandwich panels are shown in Figure 3. Joints have traditionally had an outer rain protection of sealant on backing rod and a small air gap connected to small openings for depressurisation, drainage and ventilation ("TDV tubes", approximately $10 \mathrm{~mm}$ in diameter) in each cross point of vertical and horizontal joints. The new solution suggests exchanging the sealant/backing 
rod with a pre-compressed joint sealing tape between concrete panels, excluding the small TDV tubes.

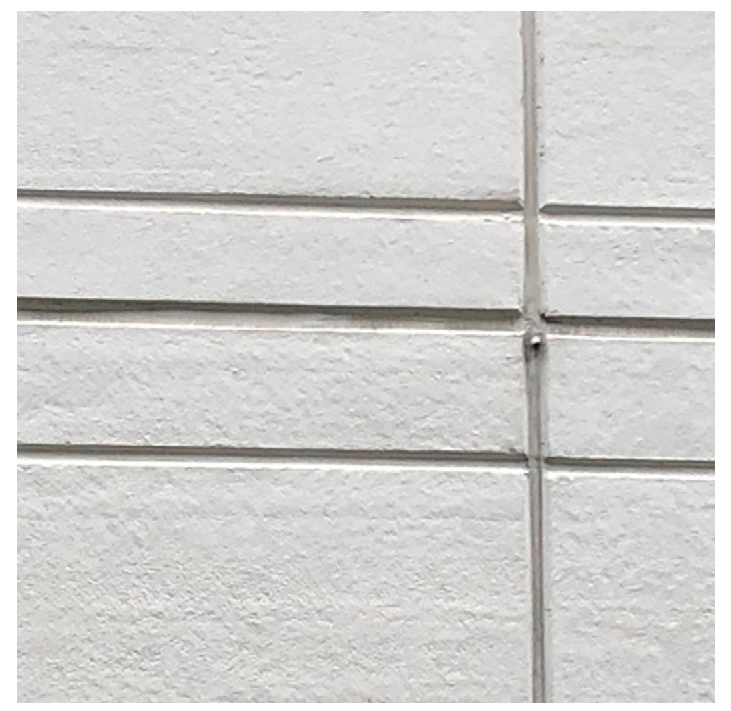

(a)

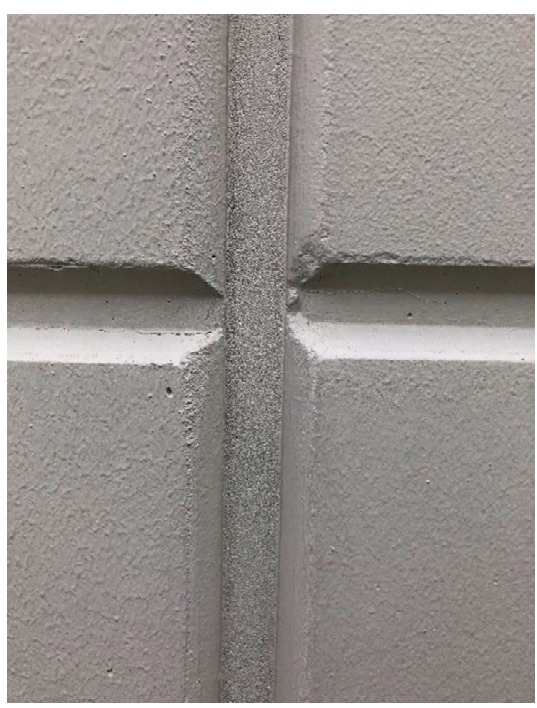

(b)

Figure 3. Example of two precast concrete panel facades: (a) horizontal and vertical joints using sealant/backing rod and a TDV tube where horizontal and vertical joints meet; (b) vertical joint using pre-compressed joint sealing tape.

The size of the joints should be designed to handle dimensional changes in the concrete panels and, thus, the width is dependent on the size of the panels, the agreed tolerances and the flexibility of the sealing method used. The suggested solution is shown in Figure 2. In practice, several variations of the solution were identified. Common alternatives identified were (1) excluding the air gap behind sealing tape, (2) using complementary tubes for depressurisation, drainage and ventilation and /or (3) using complementary sealant outside the pre-compressed joint sealing tape. Potential of drainage at the base of the building can also differ dependent on design in details.

Limitations. This assessment is a general assessment of the system solution concerning the identified targets and does not replace risk assessment in the specific design in construction project. The assessment does not cover areas other than the identified targets. Legal, contractual or work safety issues were not handled. Implementation of the solution in construction or safety issues were not handled.

\section{Tollgate 1}

The scope was defined as the design solution recommended by suppliers. The solution was perceived as of interest but with consequences for the design-build contractor if the targets were not fulfilled. However, there were no indications of obvious unacceptable obstacles when setting up the scope. Based on the findings when setting up the scope, the contractor is recommended to accept the scope as is and to proceed with a qualitative assessment concerning fulfilling targets for joint sealing tape in precast concrete sandwich panel facades.

\section{Results}

\subsection{Qualitative Assessment}

There is an abundance of literature on the technical aspects of precast concrete sandwich panels, while specific literature on the performance of joints is scarce. There are also European standards dealing with different aspects of precast concrete sandwich panels.

The EU, Constructions Products Regulations (CPR) [10], states harmonised rules for construction products on the market in the EU. A central part of the CPR is the CE 
marking of construction products. Applicable European Standards [14,15] carry a common vocabulary and define the necessary properties to declare in relation to $\mathrm{CE}$ marking. These standards address the concrete panels and do not cover non-load-bearing joints more than the impact of the dimensional tolerances of the walls. There is no harmonised standard for pre-compressed joint sealing tapes; however, there is an EAD (European Assessment Document) for "joint sealing tape on the basis of a pre-compressed flexible polyurethane foam for sealing around windows and joints in building facades" [2]. The EAD issues essential characteristics of the sealing tape as well as method and criteria accordingly for assessing the performance, namely, reaction to fire, driving rain tightness, water vapour diffusion resistance, air permeability, resistance to high and low temperatures, resistance to UV-radiation, resistance to heat aging and compatibility to adjoining construction. The EAD applies a service life of 10 years. A previous document, the CUAP (Common Understanding on the Assessment Procedure), was earlier used for issuing the declaration of performance. Based on these documents, there was the possibility of issuing an ETA and, thus, achieving a CE marking of products. In addition, there is a German product standard for pre-compressed joint sealing tapes [16]. The DIN 18542 standard states requirements and test methods for impregnated sealing tapes made of cellular plastics, which are used for sealing outside wall joints that are compressed when built in. Both material parameters and performance are covered.

Precast concrete associations sometimes provide guidelines or other documentation for both panels and jointing techniques. In Sweden, preferred detailed designs of joints were a part of a handbook published and updated during the last decades of the 20th century [17]; however, this publication is no longer maintained. The Swedish Concrete Association, representing precast concrete panel manufacturers, claims pre-compressed sealing tape is not commonly used today (personal communication, 17 September 2020). Only one out of eight leading suppliers of precast concrete sandwich panels to the Swedish market stated using pre-compressed sealing tape on a regular basis in October 2020. Two others indicated some experience, while others did not use the solution at all. The supplier that used the solution provided a few reference cases; however, the cases were recently constructed or under construction and did not hold any evaluation.

The sealant construction industry can also provide guidelines on sealing of joints in precast concrete facades. Neither the Swedish precast industry nor the sealant construction industry in Sweden provide guidance on pre-compressed sealing tapes. An international outlook, with answers from five countries, show the solution is used in several other countries; however, only in Germany is the solution recommended by a precast concrete trade association (www.fbd.de (accessed on 27 October 2020)) with reference to the DIN standard [16]. In Denmark, the solution was mentioned as an option by the sealant contractors' association (http:/ / www.fugeguiden.dk/ (accessed on 9 October 2020)) but with the solution only briefly described.

The suppliers of pre-compressed sealing tape provide technical data on their products, both as a declaration of performance in line with CE marking and as other technical information. Typically, fire classification, exposure class, thermal conductivity, vapour resistivity, resistance to root penetration, air permeability, weather tightness driving rain, compatibility, life expectancy, performance guarantee and service temperature are given. Draining capacity is not documented but informally stated as high if substantial water pressure is applied (up to $200 \mathrm{~mm}$ ). The suppliers of sealing tape provided a few reference cases. The oldest of the Swedish reference cases is from 2011; however, the performance was not formally documented, and the design of the joint was not according to current recommendations. Reference projects according to current recommendations were significantly newer. None of the provided reference cases provided technical documentation. Instead, the suppliers referred to widespread use in Europe.

In a paper on precast concrete sandwich panels and their innovations [18], it was stated that innovation on concrete material, insultation material and on structural wythe (panel) connections enable new designs. However, the issue of the novelty of joints between panels 
was not addressed. Studies on pre-compressed joint sealing tape in joints in precast concrete sandwich facades are scarce, only [3] examined the performance of sealing tape in joints using mock-ups with four different joint configurations. The authors concluded that sealing tape should not be used solely but in combination with silicon applied to the surface to achieve a viable option. They also emphasised the importance of the design of details in the facade and proper instructions and training. Recently, [19] has performed water penetration testing of joint sealing tape in a concrete panel set-up applying driving rain under pulsating air pressure, where the tests indicated water penetration through detailing in connection to windows and balconies, and through joints already at low pressure differences. In [20], pre-compressed joint sealing tapes for window applications were studied, showing leakage through joints, and a large variation between different products. There are other studies indicating some occurrence of leakage into precast concrete sandwich panels in general. A study in [21] investigated leakage through imperfections in joints using soft mastic on a backing rod. Both vertical and horizontal joints were found to cause leakage when exposed to wind-driven rain pressure. In [22], 110 facades, some of which were sandwich panels, were tested in a laboratory with a failure rate of more than $90 \%$. For the horizontal joints of sandwich panels, the fail/leakage prevalence was approximately $60 \%$. The experiences of the study indicate that it is difficult to visually detect a failing detail. A survey among practitioners [1] confirmed the occurrence of leakage in precast concrete sandwich facades, where most of the respondents stated that leakage occurred frequently (more often than rare) and that the most common path given for leakage was through horizontal and vertical joints between panels, followed by leakage in coupling to other building parts and components as well as bushings. These studies neither specifically studied the new solution nor was the design of the joint studied in detail. In conclusion, driving rain is an issue in precast concrete facades, and a new solution is welcomed by industry due to the issues of moisture safety for the traditional solution. However, the new solution holds a lack of documented performance too.

The width of joints between panels are affected by variations due to the manufacturing tolerances and mounting. Precast concrete panels are often mounted with an agreed total tolerance according to class A or class B according to [23], allowing for a deviation of the joint width at site of \pm 6 or $\pm 8 \mathrm{~mm}$, respectively. In addition to the tolerances, the width are affected by different natural dimensional changes. The size of the temperature-dependent expansion coefficient of the precast concrete panels is in the range of $11 \times 10^{-6} \mathrm{~m} / \mathrm{mK}$, causing a maximum temperature expansion span of approximately $7 \mathrm{~mm}$ using a temperature difference of $75 \mathrm{~K}$ and length of panel $8 \mathrm{~m}$. The joints are also affected by moisturerelated dimensional changes, both reversible (ambient moisture variations) and irreversible (shrinkage related to drying out). Even though these moisture-related variations are not negligible, they are often neglected as the former is often counteracted by the temperature variations and the latter might be counteracted by the shrinkage of the structure. If they are considered, they are probably in the range of $0.05 \%$ each for normal conditions [24]. These are also usually slower processes than the temperature-related process. Traditionally, the width of joints has been designed based on the use of sealants on backing rods. There is a Swedish trade standard [24] for sealant contractors, stipulating joints to be between 12 and $45 \mathrm{~mm}$ and, as a rule of thumb, at least 1/500 of both the adjacent panels based on the use of sealant in class F25LM [25]. The sealant F25LM was tested to have a movement capability of $25 \%$ according to applicable standards [26]. The rule of thumb is only valid for concrete structures and an outer panel of concrete free to move. Some examples of joint widths and corresponding sealing tapes are shown in Table 3. However, in practice, the joints are usually not calculated in detail but rather chosen based on dimensions of panels, aesthetics and other preferences and often in the lower range (or below). The practitioners within the expert group estimate that four different widths of sealing tapes are used in every project due to the varying joint sizes, where the most used width at site is around $20 \mathrm{~mm}$, with a spread between 10 and $40 \mathrm{~mm}$. 
Table 3. Panel width and corresponding joint widths based on the rule of thumb for sealants $[23,24]$. Based on two equally sized panels.

\begin{tabular}{cccc}
\hline Panel Width & Temperature Movement & Joint Width, Theoretic * & Joint Width, Actual ** \\
\hline $4 \mathrm{~m}$ & $3 \mathrm{~mm}$ & $16 \mathrm{~mm}$ & $8-24 \mathrm{~mm}$ \\
$6 \mathrm{~m}$ & $5 \mathrm{~mm}$ & $24 \mathrm{~mm}$ & $16-30 \mathrm{~mm}$ \\
$8 \mathrm{~m}$ & $7 \mathrm{~mm}$ & $32 \mathrm{~mm}$ & $24-40 \mathrm{~mm}$ \\
\hline
\end{tabular}

* Calculated using rule of thumb [23,24]. ** Based on class B in [23].

The pre-compressed joint sealing tape is available in several dimensions, a typical example covers gaps of 17-32 (24.5 \pm 7.5$) \mathrm{mm}$. Compared to the F25LM sealants, movement of the joint has an amplitude of approximately $30 \%$. It is important to measure the width at site, estimate the temperature movement dependent on ambient conditions and chose a suitable width of the pre-compressed joint sealing tape. The depth of the sealing tape is commonly in the same range as the width. The length of the sealing tape is relatively short, for the relevant dimensions between 5.2 to $2.7 \mathrm{~m}$ and, thus creating multiple joints end to end of the sealing tape. The product is compressed when applied and then typically expands approximately up to double in size. There are neither strict restrictions on climate conditions while mounting the pre-compressed joint sealing tape nor any restrictions on the conditions of the surfaces. However, the prevailing hygrothermal conditions affect the joint size and should be considered while choosing the product. For multifamily dwellings with an average facade with average-sized joints, the joints constitute less than $1 \%$ of the facade.

\subsubsection{Risk Identification Workshop}

A risk identification workshop was performed divided into two digital events, using one digital meeting for the risk identification, followed by an online survey for exploring uncertainties. At the workshop, anticipated possibilities concerning the new technical solution were identified. The possibility with the highest perceived impact was high productivity as installation of joint material is less weather dependent compared to traditional solution, together with a faster production rate and lower moisture loads due to the shorter wet phase. These possibilities are likely to be the main driving forces for applying the solution.

Concerning risks related to targets, a total of twelve risk clusters were identified, each with several influencing factors adding up to 37 individual factors. The importance of the identified risk clusters was assessed (Table 4). The identified risk of unacceptable aging was decided to be of importance but handled within the other studied risk clusters due to the strong interconnections to the other risk clusters.

Table 4. Identified risk clusters and perceived importance to fulfilment of performance requirements. The risk clusters in bold text were selected as being of special interest.

\begin{tabular}{cccc}
\hline Target & Stage/Location & Identified Risk & Votes \\
\hline 3 & Operation/Material & Leakage: Material & 2 \\
\hline 3 & Operation/Material & Leakage: Connection to panel & $\mathbf{7 2}$ \\
\hline 3 & Operation/Panel & Water trapping: Material & 6 \\
\hline 3 & Operation/Material & Water trapping: Panel & $\mathbf{9}$ \\
\hline 3 & Operation/Panel & Aesthetics unacceptable & $\mathbf{8}$ \\
\hline $\mathbf{8}$ & Operation/Material & Aging unacceptable & 7 \\
\hline $1,3,8$ & Operation/Material & Fire safety issues & 0 \\
\hline 2 & Operation/Panel & Maintenance issues & 3 \\
\hline 8 & Operation/Material & Costs unacceptable & 2 \\
\hline- & Operation/Panel & Environmental issues & 1 \\
\hline
\end{tabular}


The expert panel was asked to assess the importance of different influencing factors for each of the four risk clusters of special interest (Figure 4). For this purpose, the earlier identified 37 influencing factors were also transformed into a total of eleven clustered factors. The influence of clustered factors was assessed similar to the risk clusters, except for the risk cluster concerning Water trapping: panel, which had less of a focus on Workmanship and more on Loads, Choice of product, and Design of drainage openings. The second step was a general assessment of uncertainties and lack of knowledge. The largest uncertainties were identified in the areas Organisation and knowledge and Drainage. A large variation between the experts was identified. It could be noted that two of the three clustered factors with the largest perceived uncertainties or lack of knowledge-Material and product properties and Draining possibilities-were also perceived to have a large impact on risk, and these should be treated carefully.

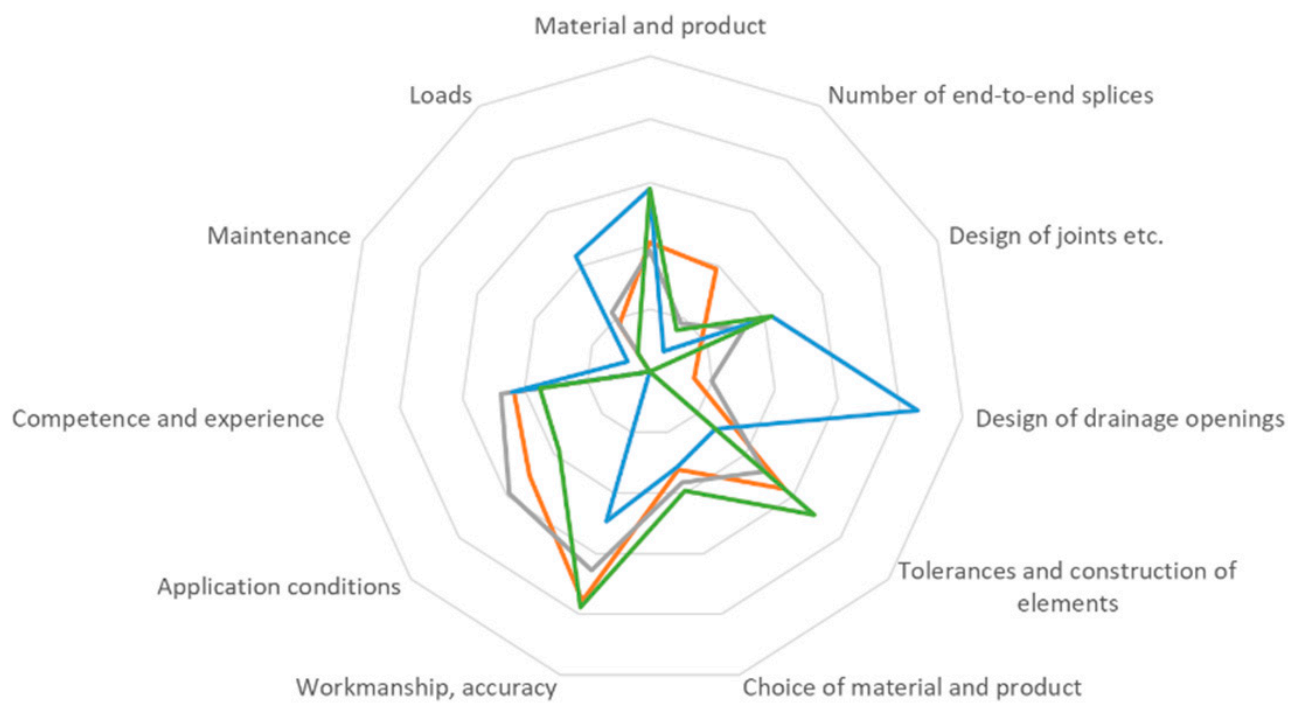

—Leakage: Splices and joints —Leakage: Contact surfaces —Drainage: System —Unacceptable aestetics

Figure 4. Assessment of the importance of influencing factors for the four selected risk clusters.

Using the results from the workshop, a fault tree was constructed using the three risk clusters concerning moisture issues (Figure 5). As earlier stated, there were large uncertainties in several factors concerning organisation, design and materials, production methods as well as loads. There were uncertainties in the overall performance, but the uncertainties were also highly dependent on detailing.

\subsubsection{Tollgate 2}

Although the given technical solution, pre-compressed sealing tape in precast concrete sandwich panel facades, has been used in other countries and has been introduced in Sweden over recent years, sufficient evaluation-theoretical assessments or reference cases have not been identified for the solution taking Swedish conditions into consideration, e.g., building code, building technology and climate. A quantitative assessment of leakage through joints and in connection to panels as well as water trapping in panels would provide valuable input for decision making and required validation of design and construction. Therefore, it is recommended to proceed to a quantitative assessment for assessing moisture balance within the wall. 


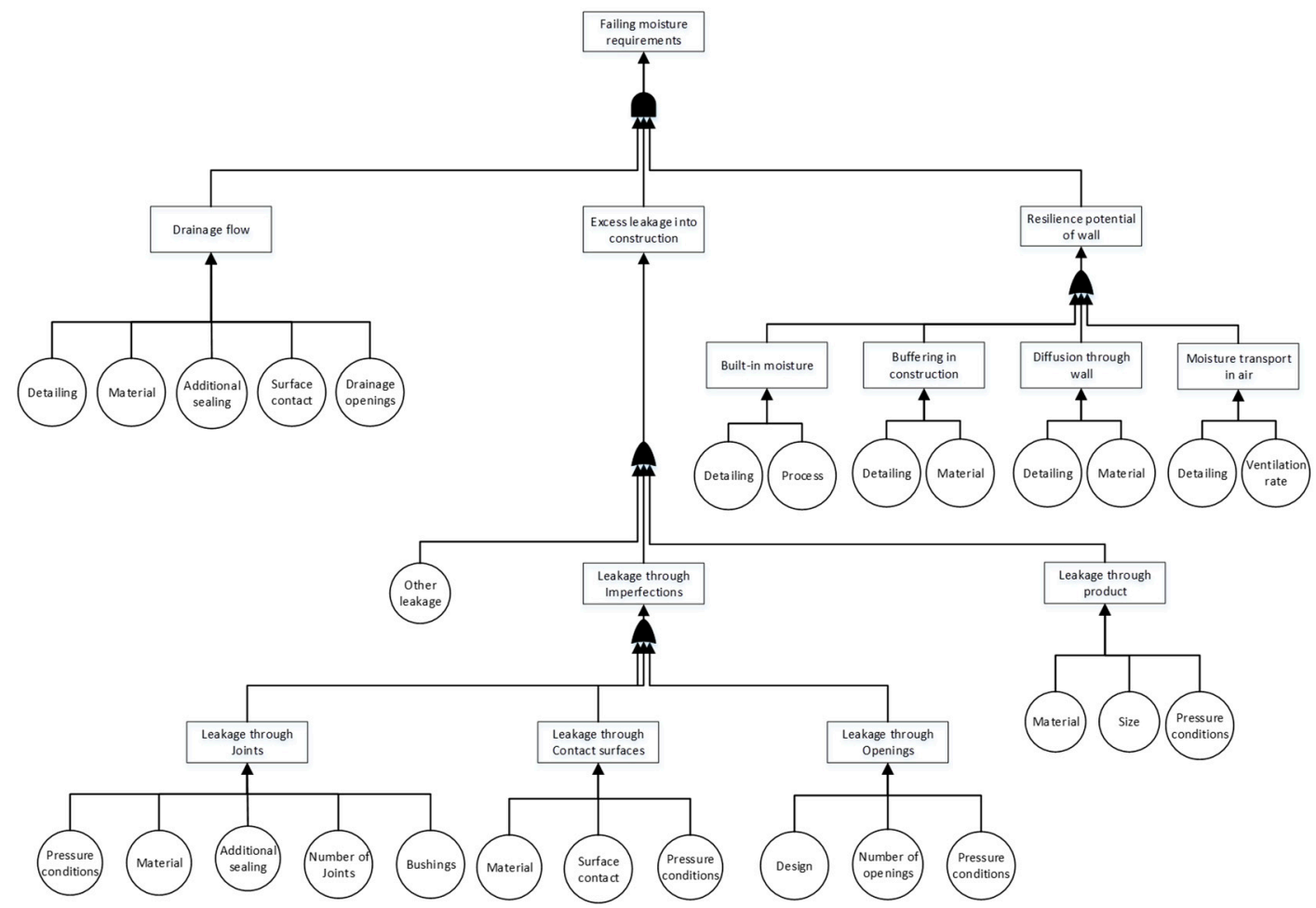

Figure 5. Fault tree for the event: Failing moisture requirements. The three risk clusters: Leakage: through joints; Leakage: Connections to panels and Water trapping: Panel, can be seen as well as other sources of leakage and resilience factors.

\subsection{Quantitative Assessment}

Based on the tree structure in Figure 5, a deterministic model for the air space within the horizontal joint was set-up in MATLAB. The model assumed a mass balance behind the joint sealing strip:

$$
G_{\text {leak }}(t)+G_{\text {diff }}(t)+G_{\text {vent }}(t)-G_{\text {buff }}(t)-G_{\text {drain }}(t)=0 \quad(\mathrm{~kg} / \mathrm{h})
$$

where $G_{\text {leak }}$ is leakage moisture flow, $G_{\text {diff }}$ is diffusion moisture flow, $G_{\text {vent }}$ is moisture flow through ventilation, $G_{b u f f}$ is moisture flow to buffer and $G_{d r a i n}$ is the resulting drainage moisture flow. Built-in moisture can be simulated by assigning buffered water at time $=0$. The details of the simplified model are shown in detail in Appendix A. Monte Carlo methods have proven to be suitable for the time-dependent, nonlinear nature of hygrothermal performance of the building envelope. Input data for simulations are determined, and relevant parameters are given as probability density functions. Simulations were run until an adequate convergence was reached. Monte Carlo methods use a high number of simulations with randomised input parameters creating a probability function for the overall performance. Thus, the uncertainties and sensitivity of the results can be analysed. Increasing the number of randomised simulations, the accuracy of simulations can be increased. Input data were determined using literature, suppliers' information, and expert judgements. An expert assessment of anticipated change of conditions in comparison to the traditional solution was used as a starting point when identifying relevant input data.

\subsubsection{Climate Data}

The outdoor climate was represented by a data set of synthetic hourly climate data for Gothenburg according to [27,28]. Climate data were based on an intermediate climate change scenario (RCP4.5). Although the lifespan of the joint sealing tape was 10 years in the EAD, or in the range of 25 years according to an expert group, the lifespan of a building is often set to 50 or 100 years and, thus, the building will have to be resilient to future climate, and climate data for 90 years were used: 2006-2095. Yearly mean values of climate 
data are given in Table 5. Driving rain on facade was calculated based on ISO 15927-3 [29]. As less than $0.5 \%$ occurs at temperatures below $0{ }^{\circ} \mathrm{C}$, the effects of snow were neglected. Facades facing south to southwest can be expected to be the most exposed to driving rain in Gothenburg. Mean wind speed and, thus, driving rain, was significantly higher than for normalised years, e.g., climate data provided for the location in the commonly used WUFI program [30] had a mean wind speed of $2.97 \mathrm{~m} / \mathrm{s}$. However, wind speeds and wind directions used were well in line with meteorological observations at two stations in Gothenburg (4.1-4.4 m/s) with south, south west or west as dominating wind directions as given in [31]. Based on Table 5 and Figure $6 a$, the south facing facade was identified as the most exposed. The corresponding relation between precipitation and driving rain is shown in Figure 6b.

Table 5. Climatic data used in the simulations for Gothenburg 2006-2096 based on $[27,28]$. Precipitation sub $0{ }^{\circ} \mathrm{C}$ and driving rain were calculated from wind speed, wind direction, precipitation and temperature.

\begin{tabular}{|c|c|c|c|c|c|}
\hline $\begin{array}{c}\text { Parameter } \\
\text { (Mean Values) }\end{array}$ & $\begin{array}{l}\text { All Data } \\
\text { 2006-2095 }\end{array}$ & $\begin{array}{c}\text { Present } \\
2006-2035\end{array}$ & $\begin{array}{c}\text { Short Term } \\
\text { 2036-2065 }\end{array}$ & $\begin{array}{c}\text { Long Term } \\
\text { 2066-2095 }\end{array}$ & Unit \\
\hline Temperature & 8.8 & 8.3 & 8.8 & 9.2 & ${ }^{\circ} \mathrm{C}$ \\
\hline Relative Humidity & 80.0 & 79.4 & 80.1 & 80.5 & $\%$ \\
\hline Precipitation & 1048 & 1008 & 1069 & 1067 & $\mathrm{~mm} / \mathrm{y}$ \\
\hline Wind Speed & 4.4 & 4.4 & 4.3 & 4.3 & $\mathrm{~m} / \mathrm{s}$ \\
\hline Longwave Radiation & 2645 & 2531 & 2650 & 2674 & $\mathrm{kWh} / \mathrm{m}^{2} / \mathrm{y}$ \\
\hline Shortwave Radiation & 1186 & 1194 & 1181 & 1183 & $\mathrm{kWh} / \mathrm{m}^{2} / \mathrm{y}$ \\
\hline Precipitation sub $0{ }^{\circ} \mathrm{C}^{*}$ & 16 & 21 & 15 & 12 & $\mathrm{~mm} / \mathrm{y}$ \\
\hline Driving Rain, $S$ ** & 516 & 497 & 516 & 535 & $\mathrm{~mm} / \mathrm{y}$ \\
\hline
\end{tabular}

* Calculated data from outdoor temperature and precipitation. ${ }^{* *}$ Calculated from hourly values of precipitation, wind speed and wind direction using [29] for an exposed facade in an exposed 10 storey building.

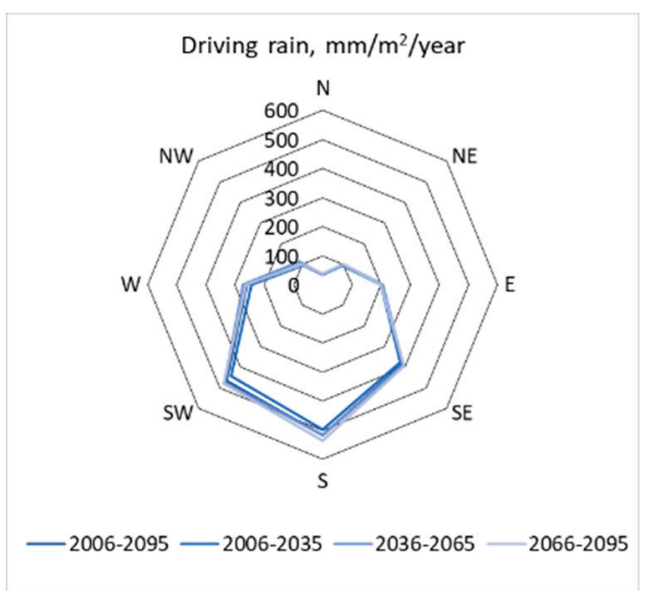

(a)

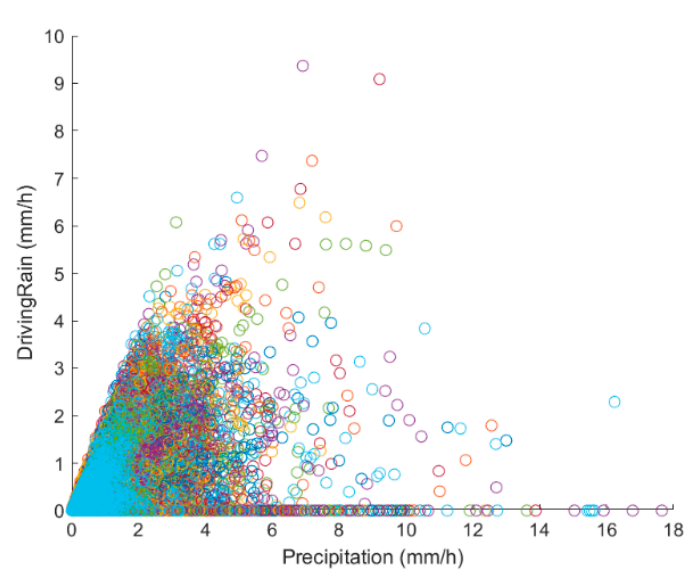

(b)

Figure 6. Driving rain on different facades of the building: (a) calculated data for driving rain on a facade in eight different directions ( $\mathrm{mm} / \mathrm{m}^{2} /$ year); (b) driving rain on the south facing facade of the building plotted against horizontal precipitation (mm/h). Hourly data year 2006-2095.

Pressure difference on wall. The pressure difference over the building envelope can also be estimated from the available climate data. Climate data can be used to study anticipated pressure on the facade. The correction term for wind speed, $\mathrm{k} \times \mathrm{z}^{\mathrm{a}}$ was set to 1.01 for the building, while the form factor for wind pressure over the building envelope, $\mathrm{C}_{\mathrm{p}}-\mathrm{C}_{\mathrm{pi}}$, was set to $0.7-(-0.3)$ [32]. Only positive pressure was denoted.

$$
\Delta \mathrm{P}_{\mathrm{w}}=\left(\mathrm{C}_{\mathrm{p}}-\mathrm{C}_{\mathrm{pi}}\right) \times \frac{\rho_{\mathrm{a}} \times\left(\cos \left(\theta_{\text {wind }}-\theta_{\text {wall }}\right) \times \mathrm{v}_{\mathrm{m}} \times \mathrm{k} \times \mathrm{z}^{\mathrm{a}}\right)^{2}}{2}(\mathrm{~Pa})
$$


Most of the time, the expected pressure over the building envelope on the studied facade was low compared to water tightness tests [12] (Figure 7). However, using hourly values probably underestimate the wind pressure by excluding gusts, where historical data for Gothenburg (SMHI Göteborg A 1995-2021 [33]) showed that the mean hourly maximum wind speed was 2.1 times the hourly value, and this ratio was used to simulate pulsating pressure. Furthermore, the pressure distribution over the building envelope (inside to outside) was unknown, and at least some of the pressure difference can be expected to be located to inner parts of the wall. For a precast concrete sandwich facade, the overall airtightness is usually quite good, where the two panels within the wall can be assumed to be more airtight.

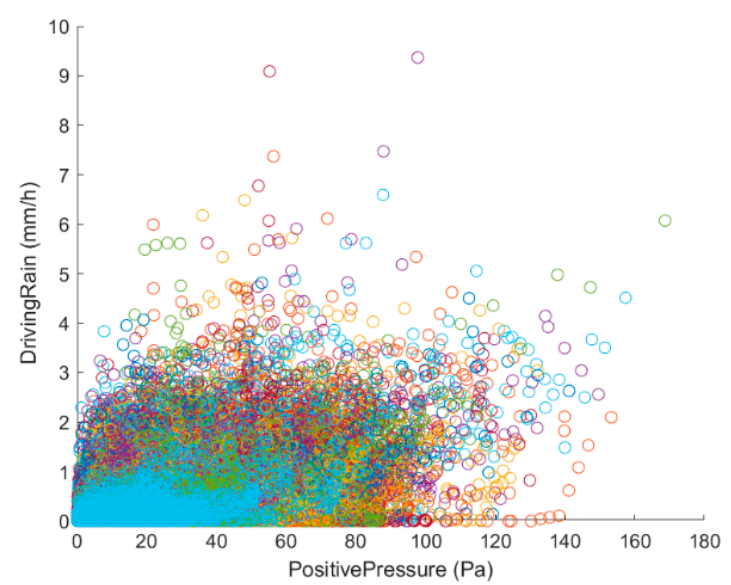

Figure 7. South facing facade 2006-2095. Hourly amount of driving rain on the facade to the expected pressure. Pressure on the facade was based on hourly climate data.

Penetration of water into the construction through imperfections can be expected to have a high impact on the moisture conditions in the wall. In hygrothermal calculations, this parameter is often set to $1 \%$ of the driving rain on the facade as suggested in, for example, [34], independent of type of facade. In [35], field and laboratory measurements suggested a value between $0.5 \%$ and $2 \%$ of water on the facade influenced by the geometry of imperfections. However, there is a significant lack of knowledge on coupling climatic conditions to pressure on building facades, pressure distribution over the building envelope and the impact of detailing. To explore the impact of driving rain for precast concrete sandwich panels, recent laboratory tests on water penetration [19] have been used. In this study, the potential of rain intrusion in precast concrete walls using joint sealing tape was explored. Two setups $(3 \times 3 \mathrm{~m})$ of, respectively, seven concrete panels using two different sealing methods in joints were used to test the resistance to driving rain using pulsating pressure up to $600 \mathrm{~Pa}$ according to [12] (Figure 8). Joints were installed according to best practice by skilled workers. Leakages were studied both visually and by measuring water intrusion in different identified leakage points, with and without arranged deficiencies, such as cracks and small holes simulating poor workmanship or weathering. The studied leakage point is denoted A19.

The laboratory testing indicated water penetration for the chosen solution. Leakage points of interest were in joints in the sealing tape, in the contact surface between sealing tape and concrete and around windows. Leakage was detected through five out of eight windows, in several cases even without pressure, indicating the need for draining of water in the wall. For specific cases of leakage in joint sealing tape, the leakage is shown in Table 6. The largest leakages related to joint sealing tape were assessed to be $0.1-0.4 \%$ of the water load on the leakage point. It should be noted that leakage could not be quantified due to the difficulty of collecting all water and the accumulation of water in materials. For the part of the wall with joint sealing tape, the pressure difference over the facade in the test might be lower than in practice due to the connection's total TDV 
tube area, which was 720 and $1050 \mathrm{~mm}^{2}$ for the two set ups. Thus, the measurements were assumed to underestimate the leakage. Compared to the traditional solution, a TDV tube indicates a leakage up to $0.09 \mathrm{l} / \mathrm{h}$ at $0-600 \mathrm{~Pa}$, while the soft mastic does not indicate leakage. However, imperfections occurring after one season can be expected in practice, where the measurements indicate leakages up to $0.1 \mathrm{l} / \mathrm{h}$ at $0-600 \mathrm{~Pa}$ for a simulated small imperfection.

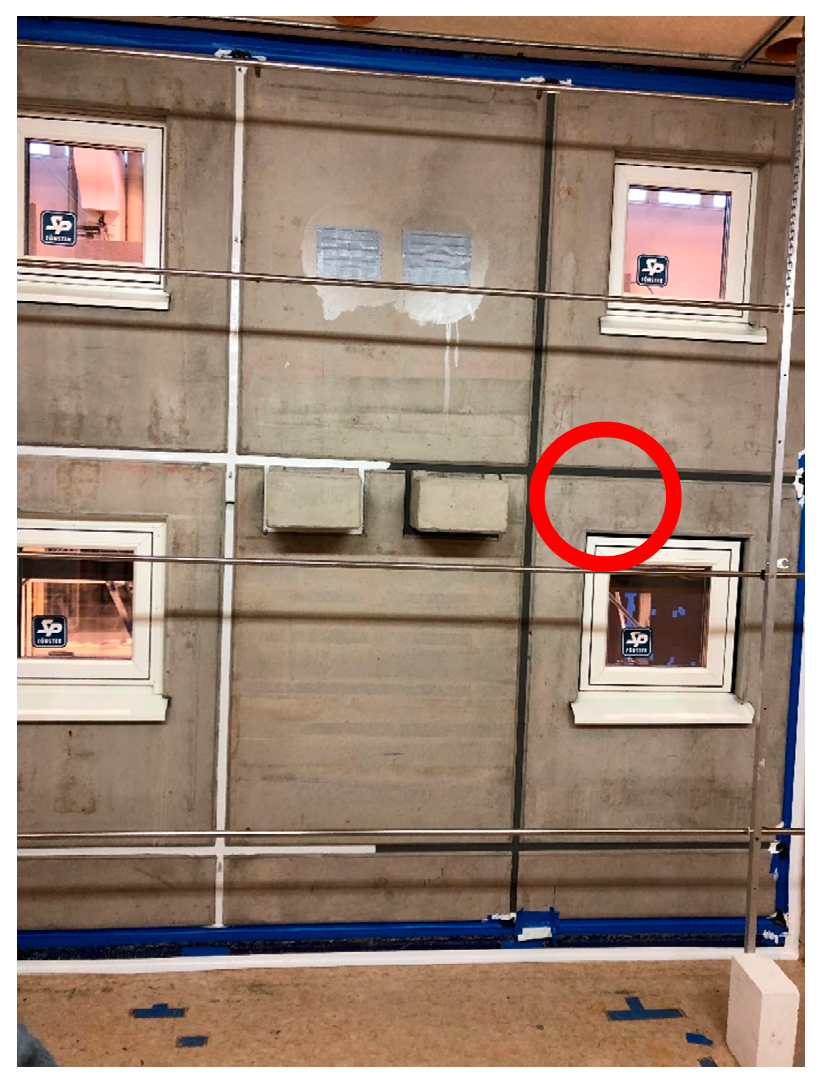

Figure 8. Laboratory concrete facade test setup, where the red circle marks the studied point A19 [19].

Table 6. Leakage in A19 from [19]. Two objects were studied in three testing rounds. The pressure steps according to the standard are given as well as the actual measured pressure over the joint sealing tape.

\begin{tabular}{cccc}
\hline Object/Test & Pressure Step (Pa) & Actual Pressure (Pa) & Leakage (kg/h) \\
\hline $1 / 1^{*}$ & $0-300$ & 187 & Indication \\
$1 / 2$ & $0-450$ & 173 & Indication \\
$1 / 3^{* *}$ & $0-150$ & 52 & 0.06 \\
$1 / 3^{* *}$ & $0-300$ & 110 & 0.27 \\
$1 / 3^{* *}$ & $0-450$ & 173 & 0.28 \\
$2 / 1^{*}$ & $0-150$ & 64 & Indication \\
$2 / 2$ & $0-450$ & 110 & 0.33 \\
$2 / 2$ & $0-600$ & 149 & 0.42 \\
$2 / 3^{* *}$ & $0-300$ & 80 & 0.67 \\
\hline
\end{tabular}

* In test 1 , the leakage was only observed visually and not measured. ${ }^{* *}$ In test 3 , modifications were made to simulate defects.

Based on the measurements in Table 6 [19], the penetration of driving rain was given as a linear dependency on facade pressure using linear regression $\left(R^{2}=0.58\right)$, where leakage was assumed to start at $0.12 \%$ of water on the facade at $52 \mathrm{~Pa}$ with a linear increase to $0.4 \%$ at $176 \mathrm{~Pa}$. To account for pulsating pressure, wind gusts were assumed to be double the hourly winds. To simulate variations, the value was given a standard deviation of $0.2 \%$ (based on the fully developed leakage). Sub-zero values were set to zero. 
Apart from the pressure differences over the building envelope, also the pressure difference distribution in the wall was of interest to the penetration of water into the wall. This depends on the air permeability of the materials and on imperfections in the construction. In the laboratory measurements, the airtightness of the tape representing the inner panel of the two setups was measured at 0.22 and $0.29 \mathrm{~L} / \mathrm{s} \cdot \mathrm{m}^{2} @ 50 \mathrm{~Pa}$, respectively. In practice, the requirement of overall air tightness of a precast concrete sandwich facade is often set to $0.3 \mathrm{~L} / \mathrm{s} \cdot \mathrm{m}^{2} @ 50 \mathrm{~Pa}$ (e.g., [36]); however, the distribution of this pressure difference in a wall is not known. For these simulations, all pressure difference is assumed over the joint sealing tape. Based on these assumptions, the penetration of driving rain into the construction was based on a fraction of the driving rain given a normal distribution (Table 7).

Table 7. Parameters of stochastic representation used in simulations.

\begin{tabular}{cccccl}
\hline Parameter & Unit & Distribution & Range & Source/Motivation \\
\hline Outdoor climate & Year & IntU & Y2006 & Y2035 & Climate data for Gothenburg [27] \\
\hline Buffer capacity & $\mathrm{kg}$ & $\mathrm{N}$ & $\mu=0.25$ & $\sigma=0.05$ & $\begin{array}{l}\text { Typical short-time buffering was set to 0.25 kg, equal } \\
\text { to 1 cm in joint. Sub-zero values were set to zero. }\end{array}$ \\
\hline Catch area & $\mathrm{m}^{2}$ & $\mathrm{U}$ & 1.4 & 2.8 & $\begin{array}{l}\text { Maximum catch area was one storey, obstructions } \\
\text { may have occurred on the half wall. }\end{array}$ \\
\hline Rain leakage & $\%$ driving rain & $\mathrm{N}$ & $\mu_{\max }=0.4$ & $\sigma_{\max }=0.25$ & $\begin{array}{l}\text { Assumption based on [19]. Linear increase from zero } \\
\text { at 52 Pa to a maximum value at 176 Pa. Sub-zero } \\
\text { values were set to zero. }\end{array}$ \\
\hline Water vapour resistance & $\mathrm{s} / \mathrm{m}$ & $\mathrm{U}$ & \multirow{2}{*}{3000} & 14,000 & $\begin{array}{l}\text { Supplier's data on joint sealing tape/WUFI } \\
\text { calculation including influence of concrete. }\end{array}$ \\
\hline
\end{tabular}

Catch area of the wall. There were uncertainties in the catch area, i.e., the area exposed to driving rain potentially leading water to the horizontal joint. The size of the catch area was dependent on the size of the facade and on the detailing, e.g., placement of balconies, windows, etc., of the studied building, which in turn was dependent on, for example, architectural considerations and the building plot. An example of the details in a facade is shown in Figure 9. For the case study, obstructions diverting water from approximately one fourth of the facade were anticipated with the assumption that water was redirected from the facade. It was given a uniform distribution (Table 7), as all outcomes were expected to be equally likely.

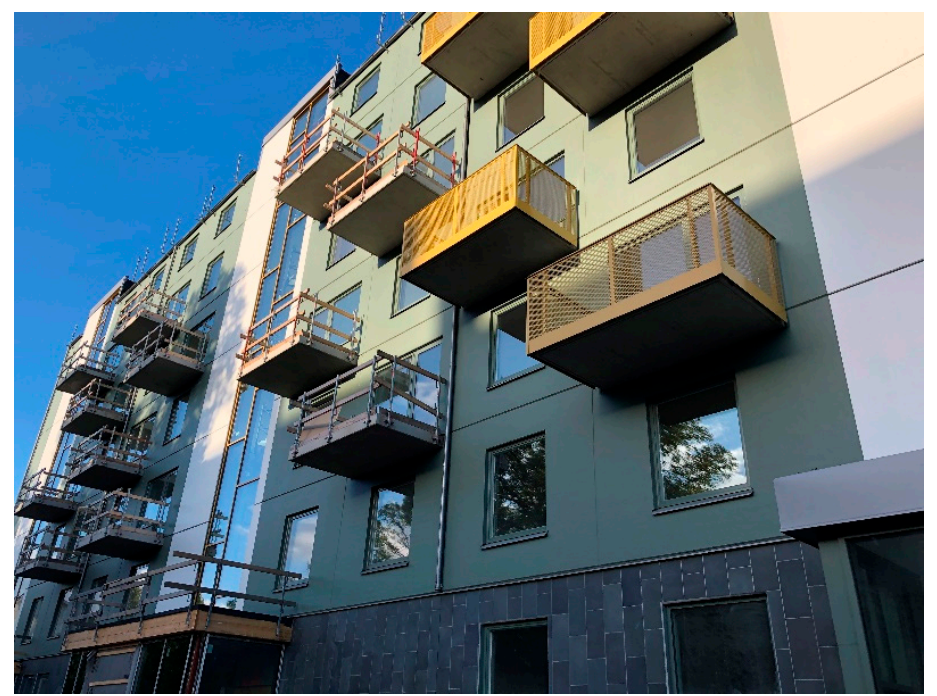

Figure 9. Example facade showing of some factors (e.g., balconies and windows) influencing the expected catch area. 
Resilience of the wall. The resilience of the wall is partly dependent on the capacity to buffer water, the amount of water possible to be held in the joint before it starts to drain. It was assumed that it could hold $0.25 \mathrm{~kg} / \mathrm{m}$ before water was drained from the joint. However, the variations were assessed as large, and the water buffering capacity was given a normal distribution with a standard deviation of $0.05 \mathrm{~kg} / \mathrm{m}$. The resilience also depended on the water vapour diffusion through the joint. Different suppliers indicated slightly different material properties and, at the same time, part of the concrete wall also possibly influenced the diffusion within the joint. An equivalent water vapour diffusion was determined by 2D WUFI calculations of the joint indicating an equivalent value in the range of 3000 and $14,000 \mathrm{~s} / \mathrm{m}$. Thus, the water vapour diffusion was given a uniform distribution, representing equivalent water vapour resistance, with or without influence of the concrete. All stochastic parameters are shown in Table 7.

Other parameters. Other uncertainties were found to have low variation or were found by initial simple parametric studies to have less influence on results and, thus, deterministic values were used (Appendix A, Table A1).

\subsubsection{Results from Simulations}

The simulations were using randomised values for the stochastic parameter. At 5000 simulated random years, convergence of the mean value and standard deviation of the leakage water and rain on catch area were considered to be sufficient (Table 8).

Table 8. Convergence of results, yearly mean and standard deviation of water drained from joint. South facing facade.

\begin{tabular}{ccccccc}
\hline \multirow{2}{*}{ Water Drainage } & \multicolumn{5}{c}{ Number of Simulated Years } & \multirow{2}{*}{ Unit } \\
\cline { 2 - 6 } & $\mathbf{5 0}$ & $\mathbf{1 0 0 0}$ & $\mathbf{2 0 0 0}$ & $\mathbf{4 0 0 0}$ & $\mathbf{5 0 0 0}$ & \\
\hline Drained water, mean & 1.50 & 2.05 & 2.01 & 2.04 & 2.04 & $\mathrm{~kg} /$ year \\
Drained water, SD & 1.70 & 1.78 & 1.75 & 1.77 & 1.78 & $\mathrm{~kg} /$ year \\
\hline
\end{tabular}

The rain hitting the wall above the joint is given as rain on catch area which can lead to water penetrating the construction for two different scenarios, all driving rain and driving rain corresponding to a pulsating pressure above $60 \mathrm{~Pa}$ (Figure 10). The resulting draining water is shown in Figure 11. It was found that the diffusion potential was far below the anticipated leakage and, therefore, the drainage needed to be addressed in design and construction.

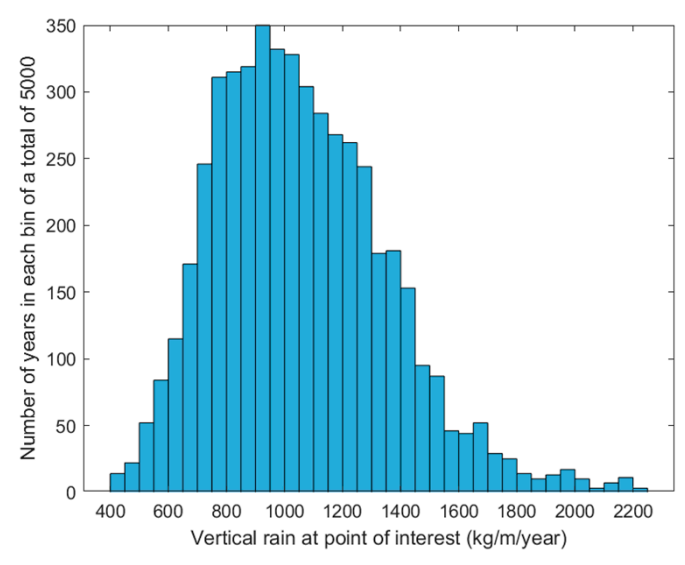

(a)

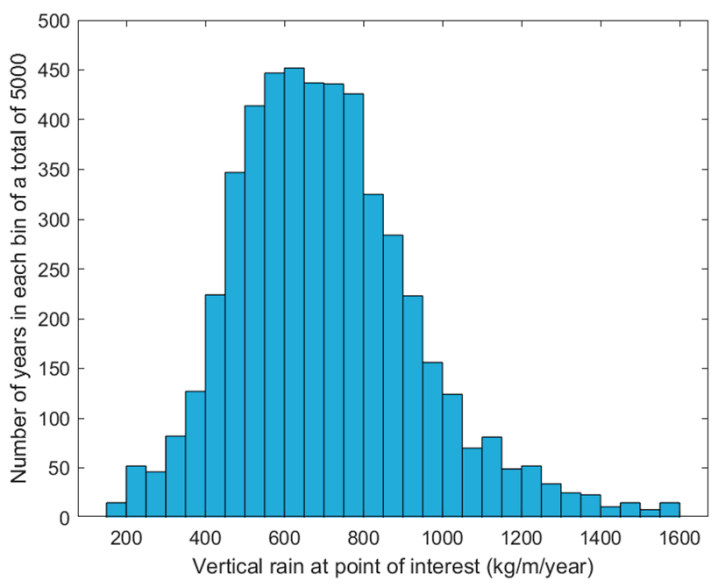

(b)

Figure 10. Rain load at the catch area of the joint in the studied facade (kg/year); (a) driving rain at all pressure differences; (b) driving rain when the pulsating pressure over the building envelope was estimated to exceed $60 \mathrm{~Pa}$. 


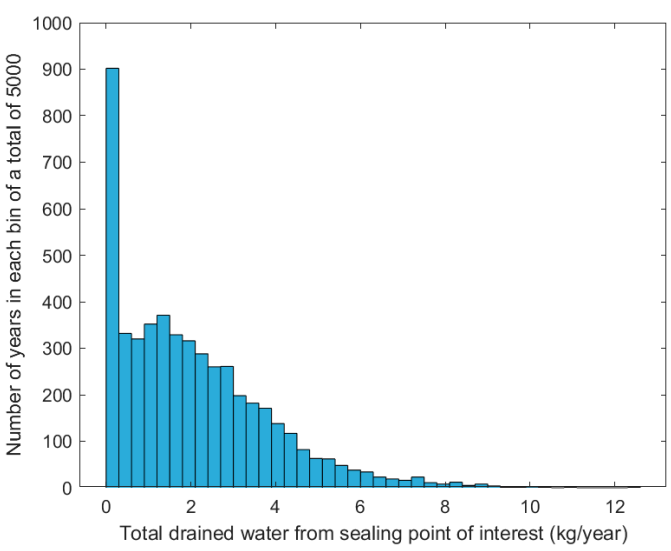

(a)

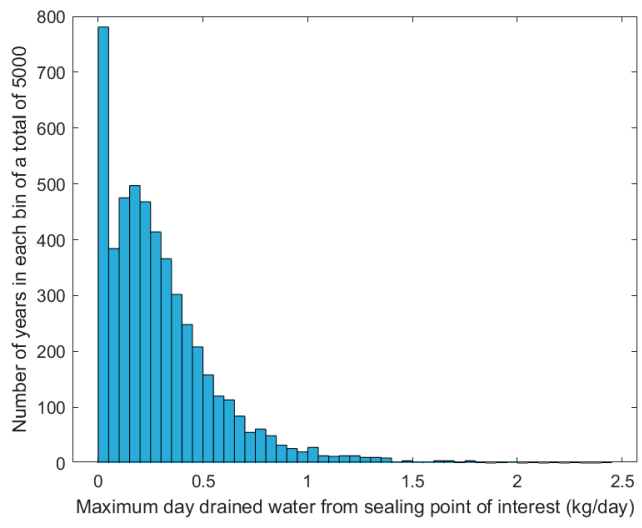

(b)

Figure 11. Resulting draining water using assumptions based on [19]: (a) total drained water from joint (kg/year); (b) yearly day maximum drained water from joint ( $\mathrm{kg} /$ day).

In Table 9, yearly mean and yearly day maximum water drainage are given for different directions of the facade, where the southern facade is seen to be the most exposed. Comparing the results for the wall in the present climate to the wall in the future climate, it can be seen that there is an expected increase in the need for drainage (Table 10). This is most significant for the 95th percentile of yearly day maximum values. As simulations were based on an intermediate climate change scenario, using other scenarios might result in larger changes.

Table 9. Comparing yearly mean and yearly day maximum water drainage for four different directions of facade 2006-2095. Mean values, standard deviation and 95th percentile.

\begin{tabular}{cccccc}
\hline Water Drainage & South & West & North & East & Unit \\
\hline Yearly, mean & 2.04 & 0.58 & 0.00 & 0.03 & $\mathrm{~kg} /$ year \\
Yearly, SD & 1.78 & 0.80 & 0.01 & 0.11 & $\mathrm{~kg} /$ year \\
Day maximum, mean & 0.30 & 0.15 & 0.00 & 0.02 & $\mathrm{~kg} / \mathrm{day}$ \\
Day maximum, SD & 0.28 & 0.22 & 0.00 & 0.05 & $\mathrm{~kg} /$ day \\
Day maximum, 95th percentile & 0.82 & 0.51 & 0.00 & 0.11 & $\mathrm{~kg} /$ day \\
\hline
\end{tabular}

Table 10. Comparing the water drainage in the joint on the south facing facade for all years (20062095), present (2006-2035) and long-term climate (2066-2095). Mean values, standard deviation and 95th percentile.

\begin{tabular}{ccccc}
\hline Water Drainage & $\begin{array}{c}\text { All Years } \\
\text { 2006-2095 }\end{array}$ & $\begin{array}{c}\text { Present } \\
\text { 2006-2035 }\end{array}$ & $\begin{array}{c}\text { Long-Term } \\
\text { 2066-2095 }\end{array}$ & Unit \\
\hline Yearly, mean & 2.04 & 1.99 & 2.13 & $\mathrm{~kg} /$ year \\
Yearly, SD & 1.78 & 1.83 & 1.89 & $\mathrm{~kg} /$ year \\
Yearly day maximum, mean & 0.30 & 0.27 & 0.33 & $\mathrm{~kg} / \mathrm{day}$ \\
Yearly day maximum, SD & 0.28 & 0.26 & 0.30 & $\mathrm{~kg} / \mathrm{day}$ \\
Yearly day maximum, 95th percentile & 0.82 & 0.75 & 0.93 & $\mathrm{~kg} /$ day \\
\hline
\end{tabular}

One other possible impact of climate change is the temperature changes affecting the performance of the joint sealing strips. In Gothenburg, Sweden, no extreme air temperatures are expected, but temperature changes affect the size of concrete elements. The south facing wall has an expected increase in yearly maximum surface temperature from 51 (2006-2035) to $53^{\circ} \mathrm{C}$ (2066-2095), and the mean temperature during the year increases by approximately $1{ }^{\circ} \mathrm{C}$, slightly higher in January and July. As the expected temperature span of the joint is calculated for $75^{\circ} \mathrm{C}$, the expected change in temperature is of minor importance, and possibly during the winter on the safe side as the sealing tape expands. 
Simulations were also made using $1 \%$ intrusion of driving rain at all pressure differences as suggested by ASHRAE [34] (Table 11). As expected, the results based on 1\% penetration of driving rain on the facade indicated a higher need for water drainage; for the studied façade, it was five times higher on a yearly basis but with a significantly lower variation. However, day maximum values were closer to previous results, and the 95th percentile only differed by $7 \%$ between the two assumptions.

Table 11. Comparing the results using of the assumption of water leakage based on measurements [19] to the ASHRAE standard [34]. Simulations for the south facing facade 2006-2095. Water drainage in the joint for all years, present and long-term climate, including mean values, standard deviation and 95th percentile.

\begin{tabular}{cccc}
\hline Water Drainage & Measurements [19] & ASHRAE [34] & Unit \\
\cline { 2 - 3 } & S, 2006-2095 & S, 2006-2095 & \\
\hline Yearly, mean & 2.04 & 10.10 & $\mathrm{~kg} / \mathrm{year}$ \\
Yearly, SD & 1.78 & 2.96 & $\mathrm{~kg} / \mathrm{year}$ \\
Yearly day maximum, mean & 0.30 & 0.52 & $\mathrm{~kg} / \mathrm{day}$ \\
Yearly day maximum, SD & 0.28 & 0.18 & $\mathrm{~kg} / \mathrm{day}$ \\
Yearly day maximum, 95th percentile & 0.82 & 0.88 & $\mathrm{~kg} / \mathrm{day}$ \\
\hline
\end{tabular}

\subsubsection{Tollgate 3}

The quantitative analysis identifies values and probabilities for rain loads on the facade and necessary water drainage of the wall to meet the targets, concluding drainage needs for exposed facades. Water draining properties of the wall and joints cannot easily be determined theoretically, as they are partly dependent on detail design and workmanship, and the suppliers do not provide validated documentation on the product or the solution on draining properties. For the studied south facing facade in Gothenburg, the need for drainage was substantial, but for the less exposed facades, the need was lower or insignificant. Due to the remaining uncertainties related to detail design in combination with potentially high draining flows, it is recommended to continue to full-scale testing in a building combined with comprehensive monitoring of moisture conditions and documentation of conditions to create a documented and evaluated reference case.

\subsection{Evaluation Reporting, Tollgate 4}

In Tollgate 4, the implementation plan of the new technical solution should be discussed along with the format of presenting evaluation results visually. Based on the evaluation, recommendations for implementation in full-scale testing in a building are given in Table 12.

Table 12. Identified risk clusters with target according to Table 2 in brackets and corresponding perceived importance to fulfilment of performance requirements. Basis of assessment is given in the table as qualitative risk assessment (QIRA) or quantitative risk assessment (QRA).

\begin{tabular}{cl}
\hline $\begin{array}{c}\text { Identified Risk } \\
\text { (Target) }\end{array}$ & \multicolumn{1}{c}{ Available Documentation and Recommended Action } \\
\hline & $\begin{array}{l}\text { Assessment: Available product documentation assessed as adequate, although products } \\
\text { tested }(7-12 \mathrm{~mm}) \text { are below used range. Products tested and classified according to } \\
\text { European standard on water tightness for windows and doors [37,38]. } \\
\text { Recommendation: Require documentation on the specific product. Product should comply } \\
\text { with national standard on driving rain class 9A. Size of product should be chosen at site } \\
\text { according to supplier's recommendation, actual width of joint and prevailing conditions. }\end{array}$ \\
& $\begin{array}{l}\text { Assessment: Available documentation on performance assessed as incomplete. The test } \\
\text { setup according to European standard on water tightness for windows and doors does not } \\
\text { necessarily cover joints in materials although a test setup for braces is suggested in the EAD. } \\
\text { Quantitative assessment indicates substantial water leakage in exposed facades, while less } \\
\text { exposed facades are less affected. } \\
\text { Recommendation: Full-scale testing in a building, combined with comprehensive monitoring } \\
\text { of moisture conditions and documentation of conditions are recommended to create a } \\
\text { documented and evaluated reference case before implementing in additional buildings. }\end{array}$ \\
\hline
\end{tabular}


Table 12. Cont.

Identified Risk (Target)

Identified Risk
(Target)

Leakage: Connection to panel (3)

Assessment: Available documentation on performance assessed as incomplete. The test setup according to European standards on water tightness for windows and doors [37] is based on slender aluminium bars, not concrete surfaces.

Recommendation: Full-scale testing in a building, combined with comprehensive monitoring of moisture conditions and documentation of conditions are recommended to create a documented and evaluated reference case before implementing in additional buildings.

Assessment: Available product documentation assessed as incomplete. Properties concerning vapour permeability are documented; however, there are no documented properties concerning water content or sorption.

Recommendation: Require documentation on specific product. Low potential of holding water is assumed positive.

Water trapping: Material (3)

Assessment: Available documentation on performance regarding drainage assessed as incomplete. No verified drainage properties of product or design are given, only assumptions draining properties differ from tests using pulsating pressure. Quantitative assessment indicates substantial need for controlled drainage of exposed facades.

Water trapping: Panel (3) Recommendation: Require documentation on draining properties using static pressure. Draining properties are assessed quantitively, indicating substantial draining water to be handled. Full-scale testing in a building, combined with comprehensive monitoring of moisture conditions and documentation of conditions are recommended to create a documented and evaluated reference case before implementing in additional buildings.

Assessment: Available documentation show examples of design. Reference cases are given.

Aesthetics unacceptable (8) Recommendation: Aesthetics should be evaluated for the specific application within the construction project based on available documentation or by visiting given reference cases.

Assessment: Available product documentation states expected life expectancy of more than 25 years, but the boundary conditions for this assessment is unclear. However, the EAD [2] states it is based on a 10 year service life. Reference to the DIN standard [16] on UV resistance and on compatibility to other materials. Critical moisture conditions are not defined. Recommendation: Require documentation on specific products, including boundary conditions, with full validation reports for assessment on applicability to prevailing conditions.

Aging unacceptable $(1,8)$ Assessment: Available documentation substandard, using national standards in other countries and providing different classifications (B and F, respectively) for same product. Recommendation: Require documentation on specific product, using applicable national standard. Include in fire safety documentation of the project.

Fire safety issues (2)

Assessment: Available product documentation exists where no maintenance issues are stated except for replacing the material after service life. However, service life is unclear (see "Aging unacceptable").

Recommendation: Require documentation on specific product and include in operation and maintenance plan of the project.

Maintenance issues (8)

Assessment: No technical issue and, thus, not handled in this assessment.Recommendation: Handle in the estimation.

Costs unacceptable (8) Assessment: Available product documentation on content existing for products. Life cycle assessment is not provided.

Environmental issues (3) Recommendation: Require documentation on specific products and check for compliance to applicable building regulations and requirements in the project.

Other (-) Recommendation: Assess and document questions arising in implementation.

\section{Discussion, Conclusions, and Future Work}

From the performed risk assessment, results were found to be both related to the technical finings and to the process. These are discussed separately.

\subsection{Discussion on Technical Findings}

Quantifying penetration of driving rain shows the possibility of substantial leakage for the studied exposed facade. This complies with studies indicating leakage into precast concrete structures due to the fact of driving rain [1,20-22] for the traditional solution and $[3,4]$ for the pre-compressed joint sealing tape. As there are few studies of pre-compressed joint sealing tapes in joints between precast concrete facades, the solution was compared to 
the traditional solution as a starting point. In [19], measurements in two laboratory tests indicated leakage in both the traditional solution and new solution and, as expected, a significant impact of leakage of other detailing, mainly windows. Overtime, it is believed the total amounts of water entering the construction can be in the same range as the traditional solution, presumably originating both from the joints and from other detailing such as windows, balconies and other adjacent structures [1]. Taking future climate change into account, including different scenarios, the variations were larger, and the probability of high drainage needs increased. Future climate is anticipated to increase loads on the solution and possible cause a failure. This risk might be slightly mitigated by an increasing temperature and related expansion of materials.

There is a lack of knowledge of the distribution of pressure differences in precast concrete walls in practice for Swedish conditions. As outlined in [39], the pressure distribution over the joint sealing tape depends on the air tightness of the inner air barrier system (panel), the air gap and the rain screen, i.e., air tightness of the joint itself. In the laboratory setup, parts of the inner panel were replaced with tape, and the air gap behind the joint sealing tape was in connection with openings (TDV tubes), whereas in reality, there are no intentional openings in the facade. In the simulations, a conservative assumption was made assuming all pressure difference occurred over the joint sealing tape. This potentially resulted in an overestimation of the pressure difference over the joint and, consequently, of the leakage.

Early assumptions indicated the main differences compared to the traditional solution to be the low water vapour resistance of the joint sealing tapes, the absence of draining/pressurisation openings and different possible imperfections. The low water vapour resistance, initially held as a key issue, was found to be of minor importance, as the leakage was only marginally affected: using ten times higher water vapour resistance, the effect on the need for drainage only increased in the range of $5 \%$. The absence of intentional draining/ventilation openings has the potential of increasing pressure difference over the joint compared to traditional solution. However, the ventilation area of the traditional solution is far too small to provide depressurisation over joints. For the studied traditional solution in [19], this area was found to be far too small to depressurise in relation to expected air tightness, indicating the traditional solution does not perform as anticipated, which has to be considered when comparing the two solutions. The knowledge of imperfections in practice is low and only briefly studied so far.

If more sensitive materials are used in wall, special concern regarding critical moisture levels must be considered. Furthermore, the simulations focused on drainage from the top floor joint. If no measures are taken, draining water from different floors potentially adds up at the base of the building, indicating a need for draining at each floor or special precautions in design should be given draining at the base level. Material properties of joint sealing tape indicate water tightness up to 600 Pa pulsating pressure according to [12]. A pressure of $600 \mathrm{~Pa}$ corresponds approximately to the pressure of $60 \mathrm{~mm}$ water in the wall, and if there are leakage paths leading inwards, the consequences could be significant. In practice, the connection between concrete surface and joint sealing tape might allow for water drainage at lower pressures, but there is no verified documentation of expected draining capacity of joints.

Even though the quantification of driving rain and its consequences holds uncertainties and significant variations-in climatic loads and material properties, as well as in detail design and workmanship - the quantification was perceived as important to the assessment. The quantification of the impact of climate loads can serve as a communication tool in design-build contractors' decision making. Furthermore, the recommendations for the design-build contractor also hold measures to reduce the remaining uncertainties by full-scale testing and monitoring of performance in a building. 


\subsection{Findings and Discussion on Evaluation Process}

As several variations of the solution were found in practice, agreeing on the scope in Tollgate 1 was crucial to ensure an efficient assessment. When evaluating a new technical solution, detailed checklists were not suitable, as they potentially were missing issues relevant to the new solution. However, the use of a general table of performance criteria was perceived beneficial. In this case Basic requirements for construction works, as defined in Annex I to the Construction Products Regulation [10], was used as a starting point. The participants of the expert group together with a literature review determined the studied risks within this structure.

The different approaches of stakeholders in the expert group were perceived as an advantage for the assessment. All identified stakeholders were committed to the task but had different experiences relevant to the issue and different approaches to the assessment. Some of the stakeholders were invested in the issue and had direct experience, while others had related knowledge of precast concrete and construction works. Stakeholders not invested in the solution ensured an investigation with less preconceptions

It was evident that adequate time must be allocated for the assessment process. Beside the actual analysis of data, allocating time for the assessment and expert group, as well as for identifying and receiving relevant documentation, require advanced planning. Although all the stakeholders were committed in the studied case, the products had a CE marking and the assessment was performed at a reasonable detailing level, the assessment took several months and, still, all required documentation for implementation were not in place, e.g., documented performance of reference cases and validated single material properties of interest. This time span is likely to be incompatible with the available time span for decision making in a design-build construction project, implying the need for the evaluation to be started before implementation in a specific project is considered. By using the predefined framework with a dedicated project manager, the new technical solution can be prequalified before implemented in the organisation's individual building projects by architects and designing engineers. However, these actors' perceptions of using the results of the prequalification in an individual project are yet to be studied.

In the risk assessment, only the new technical solution was evaluated, but in the process shortcomings in risk evaluation on performance of the traditional solution were identified. It can be expected that the more thorough investigation of new technical solutions to be implemented in industry, the more deficiencies in existing solutions will be pinpointed.

\subsection{Conclusions and Suggestions for Future Work}

A change from the traditional solution with soft mastic on backing rod to precompressed joint sealing tape in precast concrete facades might be possible if draining potential is ensured in all detailed design. Additional measures should be considered for highly exposed facades as the south facing facade in the study. This should be further explored and might include joints with a separated rain tight layer and a wind tight barrier using a ventilated and drained air space combined with meticulous measures to ensure drainage of the wall in every detail, with special focus on base of the building. For less exposed facades and locations, the impact of driving rain is significantly lower and suggested solution could be safer to implement.

Suggestions for future work:

- Further explorations of future climate scenarios, looking at different scenarios and locations;

- Laboratory testing to determine draining properties for joints using joint sealing tape;

- Full-scale testing, including measurements and documentation of joint sealing tape in precast concrete sandwich facades, is suggested to verify the results. In addition, pressure differences over joint sealing tape are of interest. Before the full-scale testing, adequate documentation should be defined for the full-scale test to qualify as a 
reference case in future qualitative assessment. This could also be scaled to a generic requirement of documentation for reference cases.

- A risk assessment framework could be further explored by establishing generic questions to be answered at the different tollgates. This would facilitate the process for the design-build contractor and, thus, potentially increase the use of the framework and reduce serial failures.

Author Contributions: Conceptualization, C.S.T.; methodology, C.S.T.; software, C.-E.H.; validation, C.S.T.; formal analysis, C.S.T. investigation, L.O. and C.S.T.; writing-original draft preparation, C.S.T.; writing-review and editing, C.S.T. and L.O.; supervision, C.-E.H. All authors have read and agreed to the published version of the manuscript.

Funding: The work is partly funded by SBUF, the Swedish Construction industry's organization for research and development: grant number 13535 and 13818.

Institutional Review Board Statement: Not applicable.

Informed Consent Statement: Not applicable.

Data Availability Statement: Not applicable.

Conflicts of Interest: The authors declare no conflict of interest.

\section{Nomenclature}

\begin{tabular}{lll}
\hline Symbol & Parameter & Unit \\
\hline$C_{\mathrm{p}}$ & Form factor (wind pressure), external & - \\
$C_{\mathrm{pi}}$ & Form factor (wind pressure), internal & - \\
$G_{\text {buff }}$ & Moisture flow to buffer & $\mathrm{kg} / \mathrm{s}$ \\
$G_{\text {diff }}$ & Moisture flow through diffusion & $\mathrm{kg} / \mathrm{s}$ \\
$G_{\text {drain }}$ & Moisture flow through draining of wall & $\mathrm{kg} / \mathrm{s}$ \\
$G_{\text {leak }}$ & Moisture flow through leakage into wall & $\mathrm{kg} / \mathrm{s}$ \\
$G_{\text {vent }}$ & Moisture flow through ventilation & $\mathrm{kg} / \mathrm{s}$ \\
$\mathrm{k} \times \mathrm{z}^{\mathrm{a}}$ & Correction term for wind speed according to xx & \\
$\Delta \mathrm{P}_{\mathrm{w}}$ & Pressure difference over building envelope due to wind & $\mathrm{Pa}$ \\
$\mathrm{v}_{\mathrm{m}}$ & Wind speed & $\mathrm{m} / \mathrm{s}$ \\
$\theta_{\text {wind }}$ & Wind direction & \\
$\theta_{\text {wall }}$ & Wall direction & $\mathrm{kg} / \mathrm{m}^{3}$ \\
$\rho_{\mathrm{a}}$ & Air density & \\
\hline
\end{tabular}

\section{Appendix A}

Simulations of moisture balance in joint are based on:

$$
\begin{gathered}
G_{\text {leak }}(t)+G_{\text {diff }}(t)+G_{\text {vent }}(t)-G_{\text {buff }}(t)-G_{\text {drain }}(t)=0 \\
G_{\text {leak }}(t)=a \times A_{d r} \times D R_{\text {facade }}(t) \\
G_{\text {diff }}(t)=A_{\text {diff,ekv }} \times 3600 \times \frac{\left(v_{\text {ext, surf }}(t)-v_{\text {airspace }}(t)\right)}{Z_{\text {ekv }}} \\
G_{\text {vent }}(t)=q_{\text {airspace }} \times\left(v_{\text {vent }}(t)-v_{\text {airspace }}(t)\right) \\
G_{\text {drain }}(t)=W_{\text {buff }}(t)-W_{\text {buff,max }} \\
W_{\text {buff }}(t)=W_{\text {buff }}(t-1)+G_{\text {buff }}(t) \times t
\end{gathered}
$$


Table A1. Deterministic parameters used in simulations.

\begin{tabular}{clccl}
\hline \multicolumn{1}{c}{ Parameter } & Unit & Value & \multicolumn{1}{c}{ Source/Motivation } \\
\hline$\theta$ & Wall direction & {$\left[{ }^{\circ}\right]$} & South & South façade exposed to high driving rain loads \\
$C_{R}$ & terrain roughness coefficient & {$[-]$} & 1.2 & {$[29]$} \\
$C_{T}$ & topography coefficient & {$[-]$} & 1 & {$[29]$} \\
$O$ & obstruction factor & {$[-]$} & 1 & {$[29]$} \\
$W$ & wall factor & {$[-]$} & 0.5 & {$[29]$} \\
$R_{1}$ & Fraction of heat resistance between exterior & {$\left[\mathrm{W} / \mathrm{m}^{2} \mathrm{~K}\right]$} & 0.13 & Industry practice, and supplier's data: $\mathrm{U}_{\text {tot }} \approx 0.15$ \\
$R_{t o t}$ & and joint air space & {$\left[{ }^{\circ} \mathrm{C}\right]$} & 21 & Industry practice, e.g., SVEBY. \\
$T_{i n t}$ & Internal temperature & {$[1 / \mathrm{h}]$} & 0 & The air space does not hold any ventilation openings. \\
$n_{V}$ & Ventilation rate of air space & {$\left[\mathrm{m}^{2}\right]$} & 0.024 & $\begin{array}{l}\text { Practice in construction industry }(\mathrm{e} . \mathrm{g} ., \\
A_{d i f f, e k v}\end{array}$ \\
$\alpha_{s o l}$ & Equivalent area of diffusion, e.g., joint area
\end{tabular}

\section{References}

1. Brycke, E.; Svensson Tengberg, C. Fukt i Prefabricerade Betongsandwichelement. (Moisture in Precast Concrete Sandwich Elements) SBUF 13651; SBUF: Stockholm, Sweden, 2019.

2. EOTA. "European Assessment Document. Joint Sealing Tape on the Basis of a Pre-Compressed Flexible Polyurethane Foam for Sealing around Windows and Joints in Building Facades," European Organisation for Technical Assessment; EOTA: Brussels, Belgium, 2018.

3. Farrington, E.S.; Anderson, T.; Grant, L.; Seraderian, R. Precast concrete-to-precast concrete facade joints using precompressed expandable foam. PCI J. 2019, 64, 80-91.

4. Van Linden, S.; Van Den Bossche, N. Comperative study on the feasibility of watertight face-sealed building joints under simulated wind-driven rain conditions. Build. Res. Inf. 2021, Feb2021, 1-15. [CrossRef]

5. Svensson Tengberg, C.; Hagentoft, C.-E. Introducing New Technical Solutions in the Swedish Construction Industry-Interviews with Key Actors. In Proceedings of the ASHRAE Thermal Performance of the Exterior Envelopes of Whole Buildings XIV International Conference, Clearwater, FL, USA, 9-12 December 2019; ASHRAE: Atlanta, GA, USA, 2019.

6. Svensson Tengberg, C.; Hagentoft, C.E. Risk Assessment Framework to Avoid Serial Failure for New Technical Solutions Applied to the Construction of a CLT Structure Resilient to Climate. Buildings 2021, 11, 247. [CrossRef]

7. Sasic, A.K.; Rode, C. Annex 55 RAP-RETRO. Framework for Probabilistic Assessment of Performance of Retrofitted Building Envelopes; Department of Civil and Environmental Engineering, Chalmers University of Technology: Göteborg, Sweden, 2015.

8. Bednar, T.; Hagentoft, C.-E. Risk Management by Probabilistic Assessment. Development of Guidelines for Practice, IEA Annex 55, RAP-RETRO; Department of Civil and Enivronmental Engineering, Chalmers University of Technology: Göteborg, Sweden, 2015.

9. Bryson, J.M. What to do when stakeholders matter. Stakeholder Identification and Analysis Techniques. Public Manag. Rev. 2004, 6, 21-53. [CrossRef]

10. European Commission. Regulation (EU) No. 305/2011 of the European Parliament and the Council of 9 March 2011 on Harmonised Conditions for the Marketing of Construction Products. Construction Product Regulation (CPR); European Commission: Brussels, Belgium, 2011.

11. Bedford, T.; Cooke, R. Probabilistic Risk Analysis: Foundations and Methods; Cambridge University Press: Cambridge, UK, 2001.

12. SS-EN12865. Hygrothermal Performance of Building Components and Building Elements-Determination of the Resistance of External Wall Systems to Driving Rain under Pulsating Air Pressure; European Committee for Standardisation: Brussels, Belgium, 2001.

13. Boverket. Boverket's Mandatory Provisions and General Recommendations, BFS 2011:6 with Amendments up to BFS 2018:4; National Board of Housing, Building and Planning: Karlskrona, Sweden, 2018.

14. EN14992:207+A1:2012. Precast Concrete Products-Wall Elements; European Committee for Standardization: Brussels, Belgium, 2012.

15. EN13369:2018. Common Rules for Precast Concrete Products; European Committee for Standardization: Brussels, Belgium, 2018.

16. DIN18542. Impregnated Sealing Tapes Made of Cellular Plastics for Sealing of Outside Wall Joints-Requirements and Testing; Deutsches Institut für Normung e. V.: Berlin, Germany, 2020.

17. Betongelementföreningen. Bygga Med Prefab: Väggar och Fogar (Building Precast: Walls and Joints); Betongelementföreningen: Solna, Sweden, 2000.

18. O'Hegarty, R.; Kinnane, O. Review of precast concrete sandwich panels and their innovations. Constr. Build. Mater. 2020, 233, 117-145. [CrossRef] 
19. Olsson, L. Regntäthet hos Prefabricerade Betongsandwichväggar Med Fönster-Och Balkonganslutningar (Rain Tightness in Precast Concrete Sandwich Facades with Windows and Balconies), SBUF13818; SBUF: Stockholm, Sweden, September 2021.

20. Van Den Bossche, N. Watertightness of Building Components: Principles, Testing and Design Guidelines; Faculteit Ingenieurswetenschappen en Architectuur, Universiteit Gent: Gent, Belgium, 2013.

21. Lacasse, M.A.; Miyauchi, H.; Hiemstra, J. Water Penetration of Cladding Components—Results from Laboratory Tests on Simulated Sealed Vertical and Horizontal Joints of Wall Cladding. J. ASTM Int. 2009, 6, 6. [CrossRef]

22. Olsson, L. Results from laboratory tests of wind driven rain tightness in more than 100 facades and weather barriers. In Nordic Symposium Building Physics; NSB: Lund, Sweden, 2014.

23. Svensk, B. Hus AMA 18 (General Material and Labour Description for House Building); Svensk Byggtjänst: Stockholm, Sweden, 2018.

24. SFR. SFR Montageanvisning nr 1: Fogning Mellan Fasadelement av Betong. (Instruction No 1: Sealing of Joints between Concrete Panels); SFR Svenska Fogbranschens Riksförbund: Perstorp, Sweden, 1991; rev 2017.

25. EN15651-1:2017. Sealants for Non-Structural Use in Joints in Buildings and Pedestrian Walkways-Part. 1: Sealants for Facade Elements; European Committee for Standardization: Brussels, Belgium, 2017.

26. ISO11600:2002. Building Construction-Jointing Products-Classification and Requirements for Sealants; The International Organization for Standardization: Geneva, Switzerland, 2002.

27. Nik, V. Making energy simulation easier for future climate-Synthesizing typical and extreme weather data sets out of regional climate models (RCMs). Appl. Energy 2016, 177, 204-226. [CrossRef]

28. Nik, V.M. Application of typical and extreme weather data sets in the hygrothermal simulation of building components for future climate-A case study for a wooden frame wall. Energy Build. 2017, 154, 30-45. [CrossRef]

29. SS-ENISO15927-3:2009. Hygrothermal Performance of Buildings-Calculation and Presentation of Climatic Data-Part. 3: Calculation of a Driving Rain Index for Vertical Surfaces from Hourly Wind and Rain Data; ISO: Geneva, Switzerland, 2009.

30. Fraunhofer IBP WUFI Pro 5 Manual. Available online: https:/ / wufi.de/en/service/downloads / (accessed on 9 June 2021).

31. Alexandersson, H. Vindstatistik för Sverige 1961-2004 (Wind Statistics for Sweden); SMHI Report 201: Norrköping, Sweden, 2006.

32. Orme, M.; Liddament, M.; Wilson, A. Numerical Data for Air Infiltration and Natural Ventilation Calculations; AIVC: Coventry, UK, 1994.

33. SMHI the Swedish Meteorological and Hydrological Institute, Open Data. Available online: www.smhi.se (accessed on 10 May 2021).

34. ASHRAE. ANSI/ASHRAE Standard 160-2016. Criteria For Moisture-Control Design Analysis in Buildings; ASHRAE: Atlanta, GA, USA, 2016.

35. Olsson, L. Driving Rain Tightness, Intrusion Rates and Phenomenology of Leakages in Defects of Façades: A New Calculation Algorithm; Chalmers University of Technology: Gothenburg, Sweden, 2018; ISBN 978-91-7597-813-0.

36. FEBY. FEBY18. Kravspecifikation för Energieffektiva Byggnader. Bostäder och Lokaler. 2019. Available online: www.feby.se (accessed on 10 June 2021).

37. EN1027:2016. Windows and Doors-Water Tightness-Test Method; European Committee for Standardization: Brussels, Belgium, 2016.

38. EN12208. Windows and Doors-Watertightness-Classification; European Committee for Standardization: Brussels, Belgium, 2000.

39. Rousseau, M.; Poirier, G.; Brown, W. Pressure Equalization in Rainscreen Wall Systems. Construction Technology Update No 17; National Research Council of Canada: Ottawa, ON, Canada, 1998.

40. Hagentoft, C.-E. Introduction to Building Physics; Studentlitteratur AB: Lund, Sweden, 2001.

41. Taha, H.; Akbari, H.; Rosenfeld, A.; Huang, J. Residential Cooling Loads and the Urban Heat Island-the Effects of Albedo. Build. Environ. 1988, 23, 271-283. [CrossRef] 